\title{
Tilapia Farming in Bangladesh: Adaptation to Climate Change
}

\author{
Mohammad Lutfar Rahman ${ }^{1,2} \mathbb{D}$, Md Shahjahan ${ }^{1}\left(\mathbb{D}\right.$ and Nesar Ahmed ${ }^{3, *} \mathbb{D}$ \\ 1 Laboratory of Fish Ecophysiology, Department of Fisheries Management, Bangladesh Agricultural University, \\ Mymensingh 2202, Bangladesh; mlrahman@bsmrau.edu.bd (M.L.R.); mdshahjahan@bau.edu.bd (M.S.) \\ 2 Department of Genetics and Fish Breeding, Bangabandhu Sheikh Mujibur Rahman Agricultural University, \\ Salna, Gazipur 1706, Bangladesh \\ 3 School of Life and Environmental Sciences, Deakin University, Burwood, VIC 3125, Australia \\ * Correspondence: n.ahmed@deakin.edu.au
}

Citation: Rahman, M.L.; Shahjahan, M.; Ahmed, N. Tilapia Farming in Bangladesh: Adaptation to Climate Change. Sustainability 2021, 13, 7657. https://doi.org/10.3390/ su13147657

Academic Editor: António Dinis Ferreira

Received: 29 May 2021

Accepted: 7 July 2021

Published: 8 July 2021

Publisher's Note: MDPI stays neutral with regard to jurisdictional claims in published maps and institutional affiliations.

Copyright: (C) 2021 by the authors Licensee MDPI, Basel, Switzerland. This article is an open access article distributed under the terms and conditions of the Creative Commons Attribution (CC BY) license (https:// creativecommons.org/licenses/by/ $4.0 /)$.

\begin{abstract}
In Bangladesh, aquaculture is critically important in terms of providing food and nutrition, sustainable livelihoods, income, and export earnings. Nevertheless, aquaculture in Bangladesh has faced recent concerns due to climate change. Aquaculture is vulnerable to a combination of climatic factors, such as global warming, rainfall variation, flood, drought, temperature fluctuation, and salinity change. Considering the vulnerability of fish production to the impacts of climate change, tilapia farming is one of the possible strategies for adaptation to climate change. The positive culture attributes of tilapia are their tolerance to low water levels and poor water quality with rainfall variation, temperature fluctuation, and salinity change. In fact, tilapia farming is possible in a wide range of water environments, including freshwater, brackish water, and saltwater conditions. We suggest that appropriate tilapia culture strategies with institutional support and collaboration with key stakeholders are needed for adaptation to environmental change.
\end{abstract}

Keywords: tilapia; aquaculture; climate change; environment; adaptation

\section{Introduction}

Aquaculture is the world's fastest growing food producing sector, with a mean annual growth rate of 5.3\% during 2001-2018 [1]. Global aquaculture production achieved 82.1 million tons in 2018, of which inland freshwater aquaculture reached 51.3 million tons $(62 \%)$, while coastal brackish water aquaculture and mariculture (aquaculture is generally practiced in three different types of locations and aquatic environments: (1) inland freshwater aquaculture; (2) coastal brackish water aquaculture; and (3) onshore and offshore marine aquaculture) yielded 30.8 million tons (38\%) [1]. Asia led world fish production with a contribution of $89 \%$ in 2018 . Globally, China is positioned first (58\% of total production) among fish producing countries, followed by India, Indonesia, Vietnam, Bangladesh, Egypt, Norway, Chile, Myanmar, and Thailand [1].

Bangladesh is recognized one of the world's most suitable countries for aquaculture practices, because of its promising agroclimatic conditions and favorable biophysical resources. A vast area of shallow water with sub-tropical climate provides perfect situations for aquaculture production. In Bangladesh, both fish production and catch were estimated to be 4.38 million tons in the 2018-2019 fiscal year (Bangladeshi fiscal year: 1 July-30 June), of which 2.49 million tons (57\%) were yielded from aquaculture, 1.23 million tons (28\%) from inland capture fisheries, and 0.66 million tons (15\%) from marine fisheries [2]. The major farming practices for aquaculture in Bangladesh are extensive, semi-intensive, and intensive polyculture and/or monoculture of Indian major carp, exotic carp, catfish, prawn, tilapia, and shrimp.

Aquaculture plays a critical role in the economy of Bangladesh, contributing to food, nutrition, sustainable livelihoods, the income of farming households and associated groups, and export earnings. Fish accounts for $60 \%$ of nationwide animal protein consumption. 
Moreover, fish contributes to $3.50 \%$ of gross domestic product (GDP), $25.72 \%$ of agricultural GDP, and $1.23 \%$ of export earnings. In 2018-2019, Bangladesh exported 33,362 tons of saltwater shrimp and freshwater prawn worth at USD 383 million [2].

Despite widespread benefits, aquaculture in Bangladesh has recently encountered concerns due to climate change, as several climatic threats to fish production have been recognized $[3,4]$. The potential effects of climate change on fish production could have serious concerns for the economy of Bangladesh. While coastal fish production is more susceptible than inland aquaculture [3], imminent climate change will critically affect overall aquaculture production. Considering exposure to the effects of environmental change on fish production, appropriate adaptation strategies should be identified to manage the challenges. Minimizing the impacts of environmental change on aquaculture will need both adaptation policies and strategies [5]. Identifying possible adaptation mechanisms and mitigation options would help to intensify resilience to climate change in aquaculture [6].

Considering vulnerability to the effects of climate change on aquaculture, one of the potential adaptation options is tilapia culture [6,7]. In Bangladesh, tilapia aquaculture has great potential, as tilapia can be produced in freshwater, brackish water, and saltwater conditions. The aim of this paper is to identify how tilapia aquaculture can adapt to climate change in Bangladesh. Moreover, it examines about tilapia culture systems, productivity, and physiological responses to climate change. Finally, we conclude with some options for how tilapia culture can be adapted to climate change.

\section{Climate Change in Bangladesh}

Geographically, Bangladesh is one of the world's vulnerable countries to climate change because of its location and climatic condition. According to the Global Climate Risk Index, Bangladesh is positioned 7th among countries susceptible to climate change [8]. Bangladesh is vulnerable to different climatic factors, including rainfall variation, flood, drought, temperature fluctuation, and salinity change [3,4].

Global warming has changed wind forms, directing to enhanced rainfall in Bangladesh. In fact, global warming alters rainfall patterns as the water holding ability of air raises $6-7 \%$ for each $1{ }^{\circ} \mathrm{C}$ increase in temperature [9]. Bangladesh is located in the massive rainfall region due to its proximity of the Himalayas in the north and the monsoon belt with the Bay of Bengal in the south. In Bangladesh, annual precipitation varied from 1400 to $4300 \mathrm{~mm}$, and the mean annual rainwater intensified at a rate of $5.52 \mathrm{~mm}$ during 19582007 [10]. Climate change has great effects on rainfall irregularity, and monsoon precipitation is projected to strengthen about $10-15 \%$ by 2030 [11].

Bangladesh is a flood-prone country which has encountered six severe floods with over 35\% of inundation since 1980 [12]. Massive rainfall is one of the reasons for intensified flooding in Bangladesh. The mean temperature in Bangladesh is predicted to increase by $1.4^{\circ} \mathrm{C}$ by 2050 and $2.4{ }^{\circ} \mathrm{C}$ by 2100 [13], and a $2{ }^{\circ} \mathrm{C}$ intensify in temperature could cause a $29 \%$ increase in flood area [14]. Moreover, river flooding is common in Bangladesh as the country has 700 rivers (Bangladesh is often called the "land of rivers" because of the extensive network of rivers crisscross the country) including 57 transboundary rivers. In Bangladesh, 14.6 million coastal people are susceptible to flood, which will increase to 18.5 million by 2050 [15].

The typical weather in the dry season of Bangladesh is drought. Bangladesh encountered 19 droughts during the last 50 years [16]. In Bangladesh, drought can be categorized into meteorological, hydrological, and seasonal drought [17]. Seasonal drought, which is common in Bangladesh, has recently intensified due to climate change. Seasonal drought is connected to inadequate precipitation due to global warming [9]. In the tropical Pacific Ocean, global warming relating to El Niño (El Niño refers to the cycle of hot temperatures that happens across the tropical Pacific Ocean) can alter rainfall into dry mode, causing drought $[18,19]$.

Coastal Bangladesh is prone to cyclones that originate in the Bay of Bengal as well as the Indian Ocean. Bangladesh was affected by 154 cyclones, including 43 severe cyclones, 
during 1877-1995 [20]. On average, an extreme cyclone affects Bangladesh every three years [12]. The intensity of cyclones has increased by $5-10 \%$ in Bangladesh [21]. Coastal Bangladesh was affected by tropical cyclone Sidr in November 2007 with financial damages of USD 1.67 billion [22]. In recent years, cyclones Nargis, Rashmi, Aila, Bijli, Giri, Mahasen, Komen, Roanu, Mora, Bulbul, and Amphan devastated coastal Bangladesh.

The coastline of Bangladesh is $710 \mathrm{~km}$ long [23]: it is a crucial zone for sea level rise because of global warming and glacier melting [24]. Bangladesh lies just $2 \mathrm{~m}$ above sea level [25]. The annual sea level rise in Bangladesh is 15.9-17.2 $\mathrm{mm}$ [26], whereas the global annual sea level rise is $2-3 \mathrm{~mm}$ [25]. A $45 \mathrm{~cm}$ sea level rise would cause $11 \%$ flooding in Bangladesh that will generate millions of people as "climate refugees" [14]. The sea level is expected to rise by $1 \mathrm{~m}$ by 2100 [27], which would affect the Sundarbans mangrove forest (the Sundarbans, which is a transboundary mangrove forest located along the mouth of the Bay of Bengal between Bangladesh and India, is the world's largest continuous mangrove forest). The sea level rise is projected to inundate $120,000 \mathrm{~km}^{2}$ of coastal Bangladesh [21].

Saltwater intrusion from the Bay of Bengal, can enter over $100 \mathrm{~km}$ towards inland [22,28], is a common problem in coastal Bangladesh. Cyclones, sea level rise, and tidal surges play critical roles in enhancing salinity [20]. Salinity in coastal rivers has recently increased to $13 \mathrm{ppt}$ in the dry season and $4 \mathrm{ppt}$ in the monsoon [29]. In Bangladesh, 1.05 million ha of coastal land has been affected by saltwater [21], an areas which is increased to 2 million ha by 2050 [19].

In the Bay of Bengal, the sea surface temperatures are growing more rapidly than in the oceans globally. The global sea surface temperature is $1{ }^{\circ} \mathrm{C}$ higher than 140 years ago [30]. During 1985-2009, the water surface temperature in the Bay of Bengal increased from 0.20 to $0.46{ }^{\circ} \mathrm{C}$ during the day and 0.30 to $0.48{ }^{\circ} \mathrm{C}$ at night, which is expected to increase from 0.35 to $0.72{ }^{\circ} \mathrm{C}$ during the day and 0.50 to $0.80^{\circ} \mathrm{C}$ at night by 2050 [31]. Even small increases in water temperature cause sub-lethal effects for tropical fish [32].

\section{Tilapia Aquaculture in Bangladesh}

\subsection{History of Tilapia Farming}

As a first exotic piscine, the Mozambique tilapia (Oreochromis mossambicus) was introduced to Bangladesh from Thailand in 1954 [33]. However, the acceptance level of this species was not satisfactory to the farmers because of its early maturation and frequent spawning behavior that leading to overcrowding and slow growth rates [34]. After two decades, in 1974, UNICEF (United Nations International Children's Emergency Fund) introduced the Chitralada strain of Nile tilapia (O. niloticus) to overcome these constrains [35], because of its hardy nature, faster growth, and high disease resistance [36]. Nonetheless, Nile tilapia also struggled as a culture species due to a lack of knowledge about management practices and biology, and thus, cannot attract farmers who have a strong affinity to carp culture, which is very popular in Bangladesh. A continued attempt was made to make tilapia popular through importing red tilapia (O. mossambicus $\times$ O. niloticus) from Thailand. Afterwards, the Bangladesh Fisheries Research Institute (BFRI) reintroduced Nile tilapia in 1987 and red tilapia in 1988 from Thailand [34]. The WorldFish Center, previously known as the International Center for Living Aquatic Resources Management (ICLARM) developed a synthetic strain of $O$. niloticus that is popularly known as Genetically Improved Farmed Tilapia (GIFT), which was further improved by the BFRI and introduced to Bangladesh in $1994[37,38]$. Moreover, the GIFT strain showed significantly better performance compared to other tilapia in numerous aspects $[39,40]$. Subsequent research was carried out to produce all male sex-reversed GIFT to avoid prolific breeding, commonly known as monosex tilapia [41].

After gradational introduction, tilapia has been becoming popular among fish farmers in Bangladesh. Tilapia aquaculture plays a vital role in fish production, distribution, marketing, and consumption, which contributes to the value adding process, and greater role in increasing food supply [42]. Tilapia is now the third most important fish species after pangas and rohu in Bangladesh (Figure 1). Due to its significant contribution to food 
production, tilapia is commonly known as "aquatic chicken" [43]. In fact, tilapia can play a major role as a source of low-priced animal protein in the same way as chicken. Tilapia has also been called as the "everyman's fish" [44].

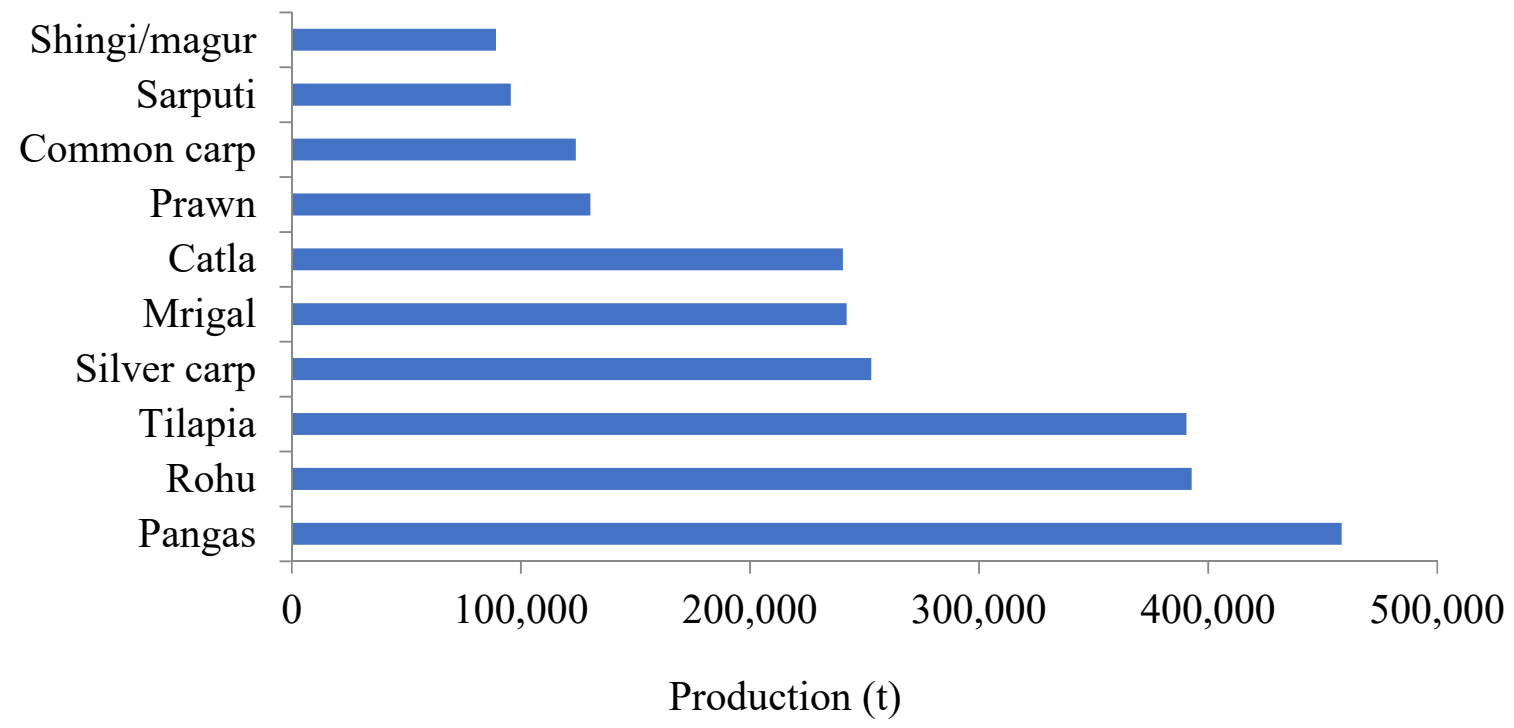

Figure 1. Species wise annual inland fish production in 2018-2019 [2].

\subsection{Tilapia Culture in Freshwater Systems}

Tilapia is well recognized as a suitable species for freshwater aquaculture systems in Bangladesh. The culture duration of tilapia is usually few months from April/May to November/December to allow more than one culture cycle [45]. Tilapia culture is mainly season based, starting prior to the summer and lasting until winter. As tilapia farming is completely dependent on hatchery-produced fry, culture season, stocking density, and culture duration are important factors. Tilapia can be cultured in small-scale, large-scale, low-input, or high-input operations in inland waterbodies. Tilapia culture can be classified into polyculture, monoculture, and integrated farming. Based on the level of input, tilapia culture can also be categorized as extensive, semi-intensive, and intensive.

Tilapia pond polyculture with other species (mostly carp) has been traditionally practiced in rural Bangladesh. Polyculture is usually practiced with a low or medium level of input under extensive or semi-intensive culture systems. Polyculture is based on the proper utilization of different ecological niches of a pond to obtain maximum yield per unit area [46]. Tilapia feed on organic particles available on the pond bottom, which are re-suspended by the sediment tabulation of carp species in the polyculture system. In this manner, tilapia can prevent the lifting of the organic load in the sediment, which in turn provides anaerobic conditions [47]. The stocking density of tilapia in polyculture system may vary depending on the culture species, natural food availability, and supplementary diet. For example, the inclusion of Nile tilapia at 2000/ha in a polyculture of bottom dweller common carp (Cyprinus carpio) and phytoplankton filter-feeding rohu (Labeo rohita), stocked at 5000 and 15,000/ha, increased the nutrient concentrations in ponds, reduced phytoplankton biomass and suspended solids, which resulted in additional fish production without affecting other cultured species [48]. Nile tilapia with a stocking density of 2200/ha in a polyculture system including filter-feeders 1000/ha of catla (Catla catla), 3000/ha of rohu (L. rohita), and 3000/ha of silver carp (Hypophthalmichthys molitrix) with 4000/ha of freshwater prawn (Macrobrachium rosenbergii) and 10,000/ha of mola (Amblypharyngodon mola) increased the production and economic benefits [49]. The stocking density of tilapia at 10,000/ha in polyculture with prawn was also found to be suitable for the growth of both tilapia and prawn $[50,51]$. In a periphyton-based polyculture system, a stocking ratio of $75 \%$ GIFT with $25 \%$ prawn at a total stocking of $20,000 /$ ha resulted in suitable fish production 
and economic returns [52]. Tilapia with prawn in polyculture system supplemented with $30 \%$ of protein also showed better performance [53].

On the contrary, monoculture allows single species tilapia production with high stocking density with high level of feed inputs, and thus, higher yield than polyculture. Although tilapia is a suitable species for polyculture due to its uninterrupted parallel production with other species, in recent times in Bangladesh have preferred to farm tilapia in monoculture. Higher growth with high stocking density under intensive or semi-intensive farming is the main key point for tilapia monoculture. A stocking density (80-200/decimal or 20,000-50,000/ha) of tilapia in monoculture can be 10-20 times higher than polyculture [54-56]. Monoculture production is also dependent on the feeding frequencies, as four times feeding frequency shows a better growth of monosex male tilapia [57].

Based on biological criteria, tilapia has potential for cage culture. Tilapia is usually produced in cages under polyculture or monoculture. Tilapia cage culture in Bangladesh is considered a very popular and effective production system in open water. Tilapia cage culture can be a successful alternative way to eliminate poverty in poor rural communities in Bangladesh [58]. Growth performance and economic analysis show that the stocking density of 50 monosex tilapia per $\mathrm{m}^{3}$ is the best for cage culture in Kaptai Lake in Bangladesh [58]. Moreover, tilapia production in cages could increase more than pond yield if they are fed with floating commercial diets supplemented with zymetin probiotics [59]. Tilapia culture is profitable if cages are designed in an inexpensive way with adaptive management techniques [60].

Tilapia culture under rice-fish farming is a potential system of fish production that would not hamper rice yield in Bangladesh. Rice-fish integration has potential to utilize land and water for the fulfillment of protein demand and increase the incomes of farmers [61]. In rice-fish coculture, tilapia is a promising species due to its higher adaptability and better growth compared to other species [62]. The stocking density of tilapia in rice-fish coculture can be varied due to extensive farming. Farm size can affect the stocking density, where a medium sized farm with 5000/ha monosex tilapia in a rainfed rice-fish ecosystem can offer better economic benefit [63]. Besides, 6 per $\mathrm{m}^{2}$ tilapia combined with common carp in integrated rice-fish system is a suitable stocking density for better growth, survival, and maximum rice production [64]. The inclusion of tilapia with $2500 /$ ha in freshwater prawn-mola polyculture in rotational rice-fish farming showed better production and profit [65]. Rice-tilapia coculture can also be more viable with the incorporation of basal fertilization in combination with compost fertilizer [66]. Integrated rice-tilapia culture, particularly seed production, could be one of the best approaches to reduce the tendency of farmers to use pesticides along with the increase in rice-fish production $[67,68]$.

In Bangladesh, tilapia is also produced in pen culture. A pen is a fixed enclosure in which the bottom is the bed of the water body. In pen aquaculture, a $1.5-2.5 \mathrm{~m}$ depth of water in canals, oxbow lakes, and dead rivers with a high eutrophic status is considered as ideal and a soft muddy to hard sandy bottom is preferable for fish growth [69]. Tilapia pen culture under floodplain aquaculture is becoming popular in rural Bangladesh.

\subsection{Coastal Brackish Water Tilapia Culture}

Shrimp (Penaeus monodon) is considered a major species for brackish water aquaculture in coastal Bangladesh, which is one of the largest sectors for earning foreign currency [70]. Recently, shrimp production has been struggling due to environmental degradation with climate change and disease outbreaks [71]. To overcome this situation, farmers have been looking for an alternative method where crop diversification, such as polyculture instead of shrimp monoculture, can play an effective role in sustainable aquaculture. Tilapia can play a vital role in polyculture to compensate for partial economic loss due to unexpected mortality of shrimp [72]. Although tilapia is a very popular freshwater aquaculture species in Bangladesh, it can grow as a diversified crop in brackish water systems [37,73]. Tilapia can augment the production of shrimp because of cumulative environmentally friendly polyculture conditions as they utilize different ecological niches [74]. In fact, tilapia feed on 
the upper water layer, filtering phytoplankton and zooplankton [47], while shrimp mostly stay on the pond bottom for grazing substrate and detritus [75]. Moreover, tilapia can tolerate various environmental hazards [76], particularly salinity stress ranging from 0 to 25 ppt $[73,77]$.

Three types of tilapia-shrimp polyculture systems are generally constructed, including simultaneous, sequential, and crop rotation systems [78]. Among different strains, GIFT and Nile tilapia would be most suitable candidate for brackish water aquaculture due to their $36-81 \%$ higher growth performance [79] and wide range of salinity tolerance compared to available salt tolerant species (grey mullet, silver barb, pangus) for shrimp polyculture. Shofiquzzoha and Alam [74] found that GIFT and shrimp coculture with $10,000 /$ ha stocking density is more prosperous than the culture of silver barb and shrimp with the same density under polyculture. Studies also recommended that a stocking density for shrimp of not more than $2 / \mathrm{m}^{2}$ [80,81], and for GIFT $1 / \mathrm{m}^{2}$ [80] is feasible under extensive culture. In addition, monosex tilapia $(10,000 / \mathrm{ha})$ with prawn $(20,000 / \mathrm{ha})$ culture showed better performance even though water salinity varied greatly, from 3 to 10.3 ppt [82].

\subsection{Productivity}

Tilapia production was not initially satisfactory in Bangladesh. However, with the advancement of culture systems, converting extensive to semi-intensive or intensive culture following monoculture instead of polyculture, the productivity of tilapia has increased considerably. Total tilapia production in inland waterbodies has recently increased from 370,017 tons in 2016-2017 to 390,559 tons in 2018-2019 (Table 1). Tilapia productivity has gradually increased in most culture systems. However, tilapia production can vary depending on culture system and species. The highest average tilapia productivity was found in pond systems under freshwater aquaculture, followed by seasonal water body and cage-pen culture. Tilapia grows to a marketable size (100-150 g) within a short culture period (2-3 months), which facilitates farmers to produce more than one crop in a year [59]. The highest annual production of monosex tilapia under monoculture is around $10,000 \mathrm{~kg} / \mathrm{ha}$ [83], and the production of tilapia is $8028 \mathrm{~kg} /$ ha with carp [84].

Table 1. Recent tilapia production under different culture systems in Bangladesh.

\begin{tabular}{|c|c|c|c|c|}
\hline \multirow{2}{*}{\multicolumn{2}{|c|}{ Culture System }} & \multicolumn{3}{|c|}{ Tilapia Production (Metric Ton) } \\
\hline & & 2016-2017 & 2017-2018 & 2018-2019 \\
\hline \multirow{3}{*}{ Freshwater aquaculture } & Pond system & 306,556 & 316,283 & 320,963 \\
\hline & Seasonal waterbody & 21,904 & 21,986 & 22,086 \\
\hline & Cage and pen culture & 5744 & 6203 & 6811 \\
\hline Brackish water aquaculture & Prawn and shrimp farm & 33,882 & 38,465 & 38,789 \\
\hline \multicolumn{2}{|c|}{ Total } & 370,017 & 384,737 & 390,559 \\
\hline
\end{tabular}

Source: Extension Data (2020).

\section{Tilapia Aquaculture: Adaptation to Climate Change}

\subsection{Low Water Quality}

The positive culture characteristics of tilapia are their tolerance to poor water quality. Tilapia usually have lower oxygen requirements than other fish, such as carp. In turbid water, tilapia can easily survive up to $200 \mathrm{mg} / \mathrm{L}$ levels of turbidity with no significant effects on specific growth rate (SGR) and feed conversion ratio (FCR) [85].

Tilapia can also tolerate certain levels of water pollution. Flooding is common in Bangladesh during the monsoon leading to intense rainfall which can inundate canals and rivers in low-lying areas. Industrial and agricultural wastes are discharged into canals and rivers. Polluted waters are mixed with floodwaters during the monsoon and spread over unavoidable flood areas. Therefore, culturing pollution tolerant species can reduce 
the risk of production loss. In this sense, tilapia can play a substantial role in tackling these conditions. Nile tilapia (O. niloticus) can tolerate high levels of waterborne cadmium, which is a common toxicant of polluted water. The highest level of cadmium recorded for Nile tilapia was $96 \mathrm{~h} \mathrm{LC} 50\left(14.8 \mathrm{mg} / \mathrm{L} \mathrm{Cd}\right.$; hardness $\left.50 \mathrm{mg} / \mathrm{L} \mathrm{CaCO}_{3}\right)$ and branchial chloride cell numbers started to recover after $24 \mathrm{~h}$ of exposure [86].

Tilapia can survive under dissolved oxygen conditions as low as below $2.3 \mathrm{mg} / \mathrm{L}$ if other factors such as temperature and $\mathrm{pH}$ remain favorable. In the rainy season, dissolved oxygen levels may reduce due to the increase in turbidity, and oxygen levels may reach as low as $2 \mathrm{mg} / \mathrm{L}$. Low dissolved oxygen levels ranging from 1-1.5 $\mathrm{mg} / \mathrm{L}$ have no effect on tilapia survival [87]. In addition, algal bloom in a fertilized pond can also reduce oxygen levels to $0.3 \mathrm{mg} / \mathrm{L}$, but no tilapia mortality was reported [88].

\subsection{Drought Condition}

As a consequence of climate change, farmers often suffer from low water volume in drought conditions because of rainfall variation in different regions of Bangladesh. Seasonal and metrological drought conditions cause inadequate access to water on fish farms. Severe droughts often cause short culture periods for fish. Prolonged droughts with low groundwater levels are also a concern for water shortage on fish farms. Year-round fish production is not feasible as a result of low water levels as well as water scarcity in ponds. Most fish farms including ponds dry up during the dry season, causing unfavorable conditions for fish, and thus fish become more stressed and crowded in low levels of water.

In the summer season, the water depth in fishponds can reduce up to $100 \mathrm{~cm}$ and sometimes lower than that. Surprisingly, tilapia can easily survive in water depths as shallow as $50 \mathrm{~cm}$, though suitable growth was recorded at around $100 \mathrm{~cm}$ water depth [89], whereas carp need a minimum of $180 \mathrm{~cm}$ water volume in the pond for their suitable growth [90]. Thus, it can be presumed that tilapia can adapt to lower water volumes than other species due to drought condition and rainfall variation.

Pumping groundwater to irrigate ponds can help tilapia culture in the dry season. Rainwater harvesting with storage facilities in ponds and ditches may also help with tilapia culture in the dry season. Using rainwater for tilapia culture may increase water use efficiency. Adjusting tilapia culture in floodplain seasonal waterbodies during monsoon may also help to cope with drought.

\subsection{Temperature Fluctuation}

Temperature change- either seasonal or daily —is a common phenomenon in aquatic environments. Fish, which are critically important inhabitants of aquatic environments, cannot avoid temperature changes. Hence, adaptations, acclimatization, and physiological responses against temperature changes are the only survival techniques of fish. It is generally perceived for living organisms that "more adaptive capability-more distribution". The worldwide distribution of tilapia confirms this perception and different studies also support this notion. Table 2 summarizes the effects of temperature changes on the physiological alterations of tilapia. The thermal effects on tilapia showed that growth performance significantly decreased after at $34^{\circ} \mathrm{C}$, although this showed a decreasing tendency towards high temperature changes [91-96]. Before they reached 5 days old tilapia (O. mossambicus) showed significantly increased percentages of deformity, and a greater number of males was induced by high temperature $\left(28\right.$ and $\left.32{ }^{\circ} \mathrm{C}\right)$ after 10 days [97]. According to Desprez and Mélard [98], a higher proportion (98\%) of male blue tilapia (Oreochromis aureus) are produced during sex determinism in high temperature regimes $\left(34^{\circ} \mathrm{C}\right)$. Non-specific immunity (lysozyme activity) of Nile tilapia can significantly decrease due to high temperature $\left(33^{\circ} \mathrm{C}\right)$ [99]. Recently, Islam et al. [96] found variable effects of high temperature $\left(37^{\circ} \mathrm{C}\right)$ on the hemato-biochemical parameters of tilapia. Here, the abundance of hemoglobin and red blood cells were significantly reduced, although the amount of white blood cells and blood glucose were increased. Higher temperature $\left(31^{\circ} \mathrm{C}\right)$ also showed positive effects on 
the metabolism of tilapia and greater growth was observed, which was supported by the increased digestive enzymes genetic expression [100].

On the other hand, at low temperatures, tilapia survivability suffers. Significantly decreased growth performance and mortality rate were perceived for tilapia below $21^{\circ} \mathrm{C}[89,101]$. It was also observed that low temperature significantly decreases hematocrit and hemoglobin parameters [101]. In addition, at temperatures below $11^{\circ} \mathrm{C}$, tilapia stop feeding, with high stress, fungal infection, and mortality due to decreases in plasma osmolarity, chloride, and sodium ion concentrations $[89,102]$. The exposure of tilapia larvae to low temperature $\left(20^{\circ} \mathrm{C}\right)$ of tilapia larvae before they were 10 days old induced a high ratio of females during sex differentiation [97]. A low temperature $\left(13^{\circ} \mathrm{C}\right)$ decreased serum glucose and cholesterol levels but increased cortisol levels of GIFT. Moreover, low temperatures also enhance catalase, glutathione, and superoxide dismutase levels in the liver with oxidative damage [103]. It was also found that reduced temperature decreases saturated fatty acid content, though it increases the polyunsaturated fatty acid content [104]. Gene expression analysis suggests that when tilapia are exposed to low-temperatures $\left(10^{\circ} \mathrm{C}\right)$, significant changes were viewed in the expression of genes associated nucleic acid and protein synthesis, amino acid metabolism, lipid and carbohydrate content, and immunity [105]. Acute lethal low temperature $\left(8^{\circ} \mathrm{C}\right)$ can disrupt kidney function and downregulate the immune-related pathway in the kidney of tilapia [106].

Tilapia is a thermophilic species. The ultimate upper lethal temperature for T. mossambica lies at $38^{\circ} \mathrm{C}$ [107]. Recent studies showed that tilapia can tolerate temperatures of up to $34^{\circ} \mathrm{C}$ without any significant effect on their growth rate [94,96]. In addition, the cortisol level, which is the stress indicator in tilapia, does not significantly increase even at $36^{\circ} \mathrm{C}$ [108], which suggests that tilapia can tolerate high temperatures, whereas for $L$. rohita, another commonly cultured species in Bangladesh, a temperature of $36^{\circ} \mathrm{C}$ may be hazardous for growth and can cause physiological damage [109-111]. The balanced sex ratio of $O$. niloticus does not deviate significantly even up to $36^{\circ} \mathrm{C}$ [92]. A study on the haemato-biochemical parameters also revealed that temperatures up to $34^{\circ} \mathrm{C}$ may not be hazardous for Nile tilapia [96]. A comparative study suggests that embryonic development and hatching of carp are significantly affected even at $33^{\circ} \mathrm{C}$ [112]. However, Nile tilapia showed faster embryonic development and better survival rates $(52.7 \%)$ after hatching at $34{ }^{\circ} \mathrm{C}$ than the control group (49.5\%) at temperature $27^{\circ} \mathrm{C}$ [113]. Tilapia may adopt some behavioral or physiological mechanisms for this high temperature tolerance. In fact, tilapia may adjust to extreme temperatures with their diurnal movement in open water. Tilapia can show other behaviors such as ventilation cessation behavior and aquatic surface respiration to prolong thermal tolerance limits both in freshwater and saltwater in response to thermal changes [114].

Different strains of Nile tilapia differ with respect to cold tolerance, but growth is usually hampered at temperatures under $16^{\circ} \mathrm{C}$. Although most fish species start to stop feeding at low temperatures (below $16^{\circ} \mathrm{C}$ ) in winter season [115], most strains of tilapia become severely stressed at $13{ }^{\circ} \mathrm{C}$. Nile tilapia started to die when water temperature fell to $11{ }^{\circ} \mathrm{C}$, and $100 \%$ death occurred by $7.4{ }^{\circ} \mathrm{C}$. Low temperature ranges from 11 to $8.4^{\circ} \mathrm{C}$ are lethal for the GIFT strain [116]. Cold acclimation can reduce triglyceride and total cholesterol in GIFT, which can help enhance cold tolerance [104]. Since the average low-temperature of Bangladesh in winter is $12.7^{\circ} \mathrm{C}$, tilapia can easily survive in winter even at low temperatures, and this low temperature tolerance can be improved through the use of $0.2 \%$ Astragalus membranaceus extract powder [117]. 
Table 2. Physiological responses of tilapia for the effects of temperature.

\begin{tabular}{|c|c|c|c|c|c|}
\hline Tilapia Strain & Temperature & Stage & $\begin{array}{c}\text { Exposure } \\
\text { Time (Day) }\end{array}$ & Effect & Reference \\
\hline $\begin{array}{c}\text { Tilapia (O. } \\
\text { mossambicus) }\end{array}$ & $20-32{ }^{\circ} \mathrm{C}$ & Larvae & $0-10$ & $\begin{array}{l}\text { Deformity significantly increase when } \\
\text { tilapia kept in high temperatures }(28 \\
\left.\text { and } 32^{\circ} \mathrm{C}\right) \text { before } 5 \text { days of age } \\
\text { Exposure to lower }\left(20^{\circ} \mathrm{C}\right) \text { temperature } \\
\text { before } 10 \text { days old induced a high } \\
\text { proportion of females }\end{array}$ & [97] \\
\hline $\begin{array}{l}\text { Nile tilapia (O. } \\
\quad \text { niloticus) }\end{array}$ & $25-37^{\circ} \mathrm{C}$ & Juvenile & 21 & $\begin{array}{l}\text { - SGR in wet weight and fecal energy } \\
\text { significantly lower in high temperature } \\
\left(37^{\circ} \mathrm{C}\right) \text { while there is no significant } \\
\text { difference at } 25-34^{\circ} \mathrm{C} \\
\text { - } \quad \text { Protein retention efficiency highest at } 28 \\
{ }^{\circ} \mathrm{C} \text { and lowest at } 37^{\circ} \mathrm{C}\end{array}$ & [94] \\
\hline
\end{tabular}

Nile tilapia $(O$. niloticus) $31-37^{\circ} \mathrm{C}$

Fingering

60
- Growth performance (weight gain, SGR) decrease at $34^{\circ} \mathrm{C}$ but significantly decline at $37^{\circ} \mathrm{C}$ compared to $31^{\circ} \mathrm{C}$
- $\quad$ Growth performance significantly decreases at 15 and $20^{\circ} \mathrm{C}$

Nile tilapia $(O$. niloticus)

$15-30{ }^{\circ} \mathrm{C} \quad$ Fingering

60

- Survival and growth rate high at 25 and

[101] $30{ }^{\circ} \mathrm{C}$
- $\quad$ Red, GIFT, and Supreme strain present similar growth and fit of exponential model at $22{ }^{\circ} \mathrm{C}$

Red, GIFT and Supreme Nile tilapia strains $22-30{ }^{\circ} \mathrm{C} \quad$ Fry

- $\quad$ GIFT and Supreme strain present higher growth rate at $30^{\circ} \mathrm{C}$ compared to Red strain
- High growth when larvae reared at thermocycle $\left(31^{\circ} \mathrm{C}: 25^{\circ} \mathrm{C}\right)$ than at $28^{\circ} \mathrm{C}$
Nile tilapia $(O$. niloticus) $25-31{ }^{\circ} \mathrm{C}$

Larvae

133 strains $16-33{ }^{\circ} \mathrm{C}$ Fry

(2)

13

- Most analyzed genes of digestive enzymes display daily rhythms in the thermocycle group
- Weight increase with the increase in temperature

\begin{tabular}{ccccc}
\hline $\begin{array}{c}\text { Nile tilapia }(\mathrm{O} . \\
\text { niloticus })\end{array}$ & $20-34^{\circ} \mathrm{C}$ & Juvenile & 56 & $\bullet \begin{array}{l}\text { Optimal temperature/dietary protein } \\
\text { level combination }\left(30^{\circ} \mathrm{C} / 40 \%\right) \text { shows } \\
\text { the greatest SGR }(2.748 \%) \text { per day }\end{array}$ \\
$\begin{array}{c}\text { Nile Tilapia }(\mathrm{O} . \\
\text { niloticus })\end{array}$ & $27-37^{\circ} \mathrm{C}$ & $\begin{array}{c}\text { Juvenile } \\
\text { and fry }\end{array}$ & $45-60$ & $\begin{array}{l}\text { Mean survival, weight, length, daily } \\
\text { growth rate, and FCR significantly } \\
\text { reduce at } 35 \text { and } 37^{\circ} \mathrm{C} \text { compared to } 27 \\
\text { and } 32^{\circ} \mathrm{C}\end{array}$
\end{tabular}


Table 2. Cont

\begin{tabular}{|c|c|c|c|c|c|}
\hline Tilapia Strain & Temperature & Stage & $\begin{array}{c}\text { Exposure } \\
\text { Time (Day) }\end{array}$ & Effect & Reference \\
\hline $\begin{array}{l}\text { Sex reversed Nile } \\
\text { tilapia }(O . \\
\text { niloticus })\end{array}$ & $25-35^{\circ} \mathrm{C}$ & Fry & 30 & $\begin{array}{l}\text { - Highest male ratio and mortality rate } \\
(91.50 \% \text { and } 17.13 \%) \text { obtained at } 35^{\circ} \mathrm{C} \\
\text { - } \quad \text { Highest significant weight gain at } 30{ }^{\circ} \mathrm{C}\end{array}$ & [120] \\
\hline $\begin{array}{l}\text { Nile tilapia (O. } \\
\quad \text { niloticus) }\end{array}$ & $5-33^{\circ} \mathrm{C}$ & Fingering & 300 & 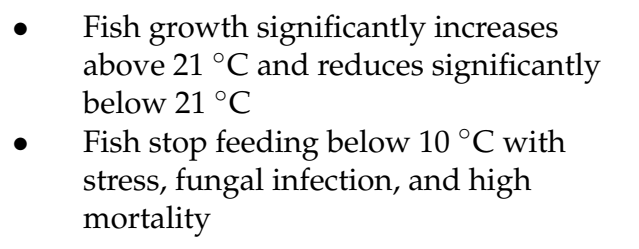 & [89] \\
\hline $\begin{array}{l}\text { Sex reversed Nile } \\
\text { tilapia }(O . \\
\text { niloticus })\end{array}$ & $26-32{ }^{\circ} \mathrm{C}$ & Fry & 28 & $\begin{array}{l}\text { Temperatures } 26-32{ }^{\circ} \mathrm{C} \text { do not affect sex } \\
\text { reversal rate, but temperatures around } \\
30{ }^{\circ} \mathrm{C} \text { improve growth and survival }\end{array}$ & [121] \\
\hline $\begin{array}{l}\text { Nile tilapia (O. } \\
\quad \text { niloticus) }\end{array}$ & $18-33^{\circ} \mathrm{C}$ & Fingering & 28 & $\begin{array}{l}\text { - Plasma lysozyme activity increases at } \\
28^{\circ} \mathrm{C} \text { after } 2-4 \text { weeks } \\
\text { - } \quad \text { A significant decrease in lysozyme } \\
\text { activity at } 33^{\circ} \mathrm{C} \text { for } 4 \text { weeks }\end{array}$ & [99] \\
\hline $\begin{array}{l}\text { Nile tilapia (O. } \\
\quad \text { niloticus) }\end{array}$ & $20-28^{\circ} \mathrm{C}$ & Fingerling & 30 & $\begin{array}{l}\text { - Growth and survival rate do not } \\
\text { significantly decrease at } 20 \text { and } 24{ }^{\circ} \mathrm{C} \\
\text { FCR increase with temperature, but } \\
\text { difference between } 28 \text { and } 30^{\circ} \mathrm{C} \text { is not } \\
\text { significant }\end{array}$ & [122] \\
\hline $\begin{array}{l}\text { Nile tilapia (O. } \\
\quad \text { niloticus) }\end{array}$ & $20-39^{\circ} \mathrm{C}$ & Juvenile & 28 & $\begin{array}{l}\text { - At } 37{ }^{\circ} \mathrm{C} \text { survival and growth average } \\
41.9 \% \text { and } 74.5 \% \text { of those fish reared at } \\
27-33^{\circ} \mathrm{C} \text {, resulting in a production loss } \\
\text { over } 70 \%\end{array}$ & [91] \\
\hline $\begin{array}{l}\text { Nile tilapia (O. } \\
\quad \text { niloticus) }\end{array}$ & $22-37^{\circ} \mathrm{C}$ & Juvenile & 28 & $\begin{array}{l}\text { - } \quad \text { Average weight significantly higher at } \\
26 \text { and } 30{ }^{\circ} \mathrm{C} \text { than at } 22 \text { and } 34{ }^{\circ} \mathrm{C} \\
\text { - } \quad \text { Daily weight gain and FCR are better at } \\
26 \text { and } 30{ }^{\circ} \mathrm{C} \\
\text { - } \quad \text { At } 37{ }^{\circ} \mathrm{C} \text { higher ratio of males }(64-80 \%) \\
\text { is produced with } 60-81 \% \text { survival }\end{array}$ & [92] \\
\hline
\end{tabular}

Bangladesh is called a country of six seasons, though three seasons (summer, autumn and winter) are mainly observed. Water temperature fluctuates throughout the country year round [123]. A survey report showed that monthwise average water temperature varied in the last five years by even more than $1^{\circ} \mathrm{C}$ in some months (Table 3 ). 
Table 3. Average water temperature in Bangladesh (data were collected from Dhaka, Chittogong and Cox's bazar areas and adopted from sea water temperature info [123]).

\begin{tabular}{ccccccc}
\hline Year & $\mathbf{2 0 1 7}$ & $\mathbf{2 0 1 8}$ & $\mathbf{2 0 1 9}$ & $\mathbf{2 0 2 0}$ & $\mathbf{2 0 2 1}$ & Temp. Fluctuation (2017-2021) \\
\hline Month & \multicolumn{7}{c}{ Temperature ${ }^{\circ} \mathbf{C}$ ) } \\
\hline January & 21.87 & 21.20 & 21.37 & 20.63 & 22.27 & 0.40 \\
February & 22.07 & 21.87 & 21.9 & 21.2 & 22.3 & 0.23 \\
March & 25.57 & 26.00 & 25.17 & 24.93 & 26.63 & 1.07 \\
April & 25.57 & 26.00 & 25.17 & 24.93 & 26.63 & 1.07 \\
May & 27.73 & 27.97 & 28.03 & 28.13 & 29.03 & 0.30 \\
June & 28.53 & 28.73 & 28.80 & 29.33 & 28.87 & 0.57 \\
July & 28.23 & 27.90 & 28.30 & 28.97 & 28.80 & 0.20 \\
August & 28.53 & 28.57 & 28.47 & 28.73 & 28.73 & 0.27 \\
September & 28.83 & 28.93 & 28.73 & 29.03 & 29.10 & 0.87 \\
October & 28.37 & 28.33 & 28.20 & 28.47 & 29.23 & 0.70 \\
November & 25.87 & 26.00 & 25.57 & 26.60 & 26.57 & -0.37 \\
December & 23.57 & 23.43 & 23.00 & 22.83 & 23.20 & \\
\hline
\end{tabular}

\subsection{Salinity Change}

Tilapia is considered as euryhaline fish which can grow comfortably both in freshwater and brackish water $[124,125]$. However, changes in water salinities can decrease growth performance and can alter the physiology of tilapia. For example, Nile tilapia can grow better when reared in water with a salinity of up to $7 \mathrm{ppt}$ (salinity is usually measured in parts per thousand (ppt), which is equivalent to grams of salt per liter water (g/L)) [126,127], while $T$. rendalli can tolerate $10 \mathrm{ppt}$ salinity with no significant effect on their growth [128]. The salinity tolerance of another strain Rufiji tilapia (Oreochromis urolepis urolepis) is higher than other tilapia strains; it is $25 \mathrm{ppt}$ in which concentration SGR, daily growth rate, and total body weight showed higher rates even than in 5 ppt salinity [129]. In fact, the salinity tolerance of tilapia may be strain specific. Since Nile tilapia is a widely cultured species, most research has performed to evaluate the salinity tolerance of this species, the findings of which are summarized in Table 4.

Although, Nile tilapia grows well in low salinity (4-7 ppt), slightly higher salinity (8 ppt) significantly decreases average weight gain $[130,131]$. Other studies indicate conflicting results of salinity in the same concentration, where the highest survival $(98 \%)$ and a linear growth in net biomass of Nile tilapia were observed at 8 ppt water salinity in recirculating systems [132], and this salinity is also recommended in biofloc technology [133]. These results suggest that rearing techniques may have the least effects on the salinity tolerance of Nile tilapia. Interestingly, the best survival and growth rate of Nile tilapia was obtained at a salinity of 16 ppt [134]. Similarly, the nutrient digestibility of Nile tilapia was increased at a salinity of $15 \mathrm{ppt}$ and showed a large impact on the distal region of the intestine [135]. Moreover, Nile tilapia cultured at $16 \mathrm{ppt}$ observed greater results than those cultured at $20 \mathrm{ppt}$ due to lower death rates and higher expression of ion-regulated genes [136].

Besides growth parameters, salinity concentration also influences hematological parameters of Nile tilapia. According to de Azevedo et al. [127], hematocrit and the erythrocyte count significantly decrease at high water salinity (14 ppt). The authors also observed histological and histopathological alterations with the increased intensity of salinity. Polyunsaturated fatty acids significantly increased up to $16 \mathrm{ppt}$ salinity [131]. The levels of $\mathrm{Na}^{+}, \mathrm{Cl}^{-}$and $\mathrm{Ca}^{2+}$ and white blood cells increased significantly in Nile tilapia when exposed to 10 and 15 ppt salinity [137].

Ideally, tilapia is a potential candidate to cope with salinity changes. Endocrine studies revealed that tilapia can compensate for greater changes in external osmolality while cultured in a tidal salinity, maintaining osmoregulatory parameters similar to seawateracclimated fish $[138,139]$. Salt tolerance genes in Nile tilapia, which play vital role during adaptation in saltwater, were also identified [140]. For saltwater adaptation, Watanabe 
et al. [141] suggested that the progeny of red tilapia spawned and cultured through early ontogenetic development in brackish water are well adapted for growth in brackish and seawater, and may have greater resistance to cold stress in seawater than progeny spawned in freshwater.

Table 4. Physiological responses of tilapia for the effects of salinity.

\begin{tabular}{|c|c|c|c|c|c|}
\hline Tilapia Strain & Salinity & Stage & $\begin{array}{c}\text { Exposure } \\
\text { Time (Day) }\end{array}$ & Effect & Reference \\
\hline $\begin{array}{l}\text { Florida Red } \\
\text { Tilapia }\end{array}$ & $4-36 \mathrm{ppt}$ & Juvenile & 70 & $\begin{array}{l}\text { Significantly better growth for progeny } \\
\text { spawned at } 18 \mathrm{ppt} \text { than } 4 \mathrm{ppt}\end{array}$ & [141] \\
\hline $\begin{array}{l}\text { Nile tilapia }(O . \\
\text { niloticus) }\end{array}$ & $0-16 \mathrm{ppt}$ & Fingerling & 70 & $\begin{array}{l}\text { Salinity } 4-8 \text { ppt suitable for biofloc } \\
\text { technology to improve growth } \\
\text { performance in initial culture phase }\end{array}$ & [133] \\
\hline $\begin{array}{l}\text { Nile tilapia }(O . \\
\text { niloticus) }\end{array}$ & $0-21 \mathrm{ppt}$ & Fry & 45 & $\begin{array}{l}\text { Culture possible up to } 7 \mathrm{ppt} \text { salinity } \\
\text { without hampering growth and } \\
\text { haematological parameters }\end{array}$ & [127] \\
\hline $\begin{array}{l}\text { Nile tilapia }(O . \\
\quad \text { niloticus) }\end{array}$ & $8-25 \mathrm{ppt}$ & Adult & 88 & $\begin{array}{l}\text { Highest survival }(98 \%) \text { and linear growth } \\
\text { in net biomass at } 8 \mathrm{ppt}\end{array}$ & [132] \\
\hline $\begin{array}{l}\text { Nile tilapia }(O . \\
\text { niloticus) }\end{array}$ & $0-15 \mathrm{ppt}$ & Fry & 96 & $\begin{array}{l}\text { The tested strains at } 5 \mathrm{ppt} \text { and returned } \\
\text { from } 15 \mathrm{ppt} \text { to freshwater revealed higher } \\
\text { growth rate than the same strains in } \\
\text { salinity and freshwater }\end{array}$ & [142] \\
\hline $\begin{array}{l}\text { Nile tilapia }(O . \\
\text { niloticus) }\end{array}$ & $8-24 \mathrm{ppt}$ & Juvenile & 15 & $\begin{array}{l}\text { No difference in antioxidant index at } 8 \\
\text { ppt relative to the control; } \\
\text { polyunsaturated fatty acid increase up to } \\
16 \mathrm{ppt}\end{array}$ & [131] \\
\hline $\begin{array}{l}\text { Tilapia } \\
\text { (Tilapiarendalli) }\end{array}$ & $5-15 \mathrm{ppt}$ & Juvenile & 70 & $\begin{array}{l}\text { Apparent digestibility of ash, crude } \\
\text { protein, fat, and gross energy } \\
\text { significantly higher at } 10 \text { ppt salinity }\end{array}$ & [128] \\
\hline $\begin{array}{l}\text { Nile tilapia }(O . \\
\text { niloticus) }\end{array}$ & $0-10 \mathrm{ppt}$ & Fingerling & 28 & $\begin{array}{l}\text { All fish survive at } 0-7 \mathrm{ppt} \text {, most } \\
\text { preferred salinity } 1 \mathrm{ppt}\end{array}$ & [126] \\
\hline $\begin{array}{l}\text { Tilapia }(O . \\
\text { mossambicus })\end{array}$ & $0-35$ ppt & Fry & 60 & $\begin{array}{l}\text { Culturing fish under tidally changing } \\
\text { salinities elicits a different pattern of } \\
\text { endocrine regulation }\end{array}$ & [143] \\
\hline $\begin{array}{l}\text { Tilapia }(O . \\
\text { mossambicus })\end{array}$ & $0-35 \mathrm{ppt}$ & Yolk-sac larvae & 120 & $\begin{array}{l}\text { Tilapia culture in a tidally changing } \\
\text { salinity has adaptive advantages } \\
\text { compared with fish produced in } \\
\text { freshwater when facing a hyperosmotic } \\
\text { challenge }\end{array}$ & [139] \\
\hline $\begin{array}{l}\text { Tilapia }(O . \\
\text { mossambicus })\end{array}$ & $0-35 \mathrm{ppt}$ & Yolk-sac fry & 120 & $\begin{array}{l}\text { Tilapia in a tidally changing salinity can } \\
\text { compensate for large changes in external } \\
\text { osmolality while maintaining } \\
\text { osmoregulatory factors within a limited } \\
\text { range close to seawater acclimated fish }\end{array}$ & [138] \\
\hline $\begin{array}{l}\text { East Java strain } \\
(\text { O. niloticus })\end{array}$ & $0-15 \mathrm{ppt}$ & Fingerling & 14 & $\begin{array}{l}\text { The concentrations of serum } \mathrm{Cl}^{-}, \mathrm{K}^{+}, \\
\mathrm{Na}^{+} \text {, and } \mathrm{Ca}^{2+} \text { in fish acclimated at } 0 \text { and } \\
5 \text { ppt are not significantly different; white } \\
\text { blood cells do not increase significantly } \\
\text { below } 10 \mathrm{ppt}\end{array}$ & [137] \\
\hline $\begin{array}{l}\text { Nile tilapia }(O . \\
\text { niloticus) }\end{array}$ & $0-15 \mathrm{ppt}$ & Fingerling & 60 & $\begin{array}{l}\text { Salinity } 15 \text { ppt increases nutrient } \\
\text { digestibility, but enhanced digestibility } \\
\text { diminished over time }\end{array}$ & [135] \\
\hline
\end{tabular}


Table 4. Cont

\begin{tabular}{|c|c|c|c|c|c|}
\hline Tilapia Strain & Salinity & Stage & $\begin{array}{c}\text { Exposure } \\
\text { Time (Day) }\end{array}$ & Effect & Reference \\
\hline $\begin{array}{l}\text { Rufiji Tilapia (O. } \\
\text { urolepis urolepis) }\end{array}$ & 5-35 ppt & Fry & 56 & $\begin{array}{l}\text { Fry reared at } 25 \mathrm{ppt} \text { salinity has highest } \\
\text { final body weight, SGR, weight gain, and } \\
\text { daily growth rate, while lowest at } 5 \mathrm{ppt}\end{array}$ & [129] \\
\hline $\begin{array}{c}\text { Nile tilapia }(O . \\
\text { niloticus) }\end{array}$ & 0-34 ppt & Fry & 22 & $\begin{array}{l}\text { The minimum and maximum osmotic } \\
\text { work rate, best survival, and growth rate } \\
\text { are obtained at } 16 \text { and } 34 \text { ppt salinity, } \\
\text { respectively }\end{array}$ & [134] \\
\hline $\begin{array}{c}\text { Nile tilapia (O. } \\
\text { niloticus) }\end{array}$ & 6-20 ppt & Young & 180 & $\begin{array}{l}\text { Fish reared at } 16 \mathrm{ppt} \text { has better } \\
\text { performance than that of } 20 \mathrm{ppt} \text { due to } \\
\text { lower morality and higher expression of } \\
\text { ion-regulated gene }\end{array}$ & [136] \\
\hline
\end{tabular}

\subsection{Disease and Parasite Prevention}

Climate change may affect water quality and disrupt host-pathogen interactions [144], sometimes creating beneficial conditions for pathogen amplification and spread [144-146], or for microbial and ecological dysbiosis [147]. Water quality disruptions stemming from climate change that may have consequences for the outbreak of marine parasites and diseases include changes in temperature, hypoxia, $\mathrm{CO}_{2}$ accumulation (reduced $\mathrm{pH}$ ), precipitation (leading to increased or decreased salinity), and cyclone frequencies and intensities $[144,148]$. Changes in water quality may result in immediate impacts on host-pathogen equilibriums or long-term impacts such as the expansion of hosts (primary and secondary) and pathogens into new regions [149]. Hence, these challenges for aquaculture need to be considered to be caused by climate change [150]. In fact, environmental change with pathogens and parasites outbreaks may be accelerated due to climate change.

Disease-resistant fish species can play critical role in mitigating these challenges, and tilapia is a suitable candidature in this context. It has been reported that tilapia are resistant to most diseases and parasites [151], and hybrid tilapia (male blue tilapia $x$ female Nile tilapia) has higher disease resistance than blue tilapia and Nile tilapia [152]. Diseaseresistant tilapia can be developed following selective breeding program against viral [153] and bacterial diseases, as host resistance is highly heritable in a Nile tilapia breeding populations with GIFT origin [154]. In addition, selective breeding can be performed with high accuracy using Bayesian models followed by marker-based and pedigree-based genomic prediction against Streptococcosis diseases [155].

Disease avoidance or removal is not an easy task if soil and water of aquatic environment are infected with pathogens. Therefore, prevention is the best choice for maintaining sustainable aquaculture. However, collecting disease-free stock, avoiding overfeeding, minimizing unnecessary handling, reducing overcrowding, and removing dead fish will reduce the risks of disease outbreak $[156,157]$. Moreover, regular cleaning and disinfection of equipment and production units must be performed to reduce the transmission of pathogens. Maintaining water quality in farming systems is also essential [157]. In addition, different feed supplements such as probiotics [158], Aloe vera [159], assam tea extract [160], Sophora flavescens [161], corncob [162], vitamin C [163], orange peels [164], green tea [165], ginger [166], and Indian lotus leaf powder [167] can increase the disease resistance of tilapia. On the other hand, novel effective vaccines can also play an important role in disease prevention and control: vaccines have been developed against most common pathogens of tilapia-Streptococcosis [168,169], motile aeromonad septicemia [170], tilapia lake virus [171], and infectious hematopoietic necrosis virus [172]. Using a treatment and diagnosis system to alert farmers to the occurrence of bacterial infection in tilapia can be a very useful tool that can reduce economic losses and labor costs in aquaculture [173]. 


\section{Conclusions}

Aquaculture in Bangladesh is susceptible to a variety of climatic factors, including global warming, rainfall variation, salinity change, and temperature fluctuation. Considering susceptibility to the impacts of environmental change on aquaculture, tilapia farming is one of the potential strategies for adaptation to climate change. Compared to other fish, tilapia can adapt to low water quality caused by rainfall variation as well as flood and drought. Tilapia can also adapt to low water volume and drought conditions. Moreover, the positive culture characteristics of tilapia are their tolerance to temperature fluctuation and salinity change. Disease-resistant fish species can play a critical role in adapting to climate change, as tilapia is a suitable fish that can resist most diseases and parasites.

For adaptation to climate change, tilapia farming is possible in a wide range of water environments, including freshwater, brackish water, and saltwater conditions. Tilapia can be produced under polyculture, monoculture, and integrated farming in pond systems, cage culture, pen culture, floodplain aquaculture, and coastal ponds. Since tilapia can easily survive in low water volume with high stocking density and short culture duration, this species can be cultured in seasonal water bodies. In addition, tilapia farming in rice fields can also adapt to changes in water level and temperatures. In fact, integrated rice-tilapia farming could be another adaptation strategy to reduce further risks of climate change. Moreover, tilapia can be cultured with brackish water species in coastal ponds as tilapia can tolerate moderate level of salinity. Ultimately, tilapia is a suitable aquaculture fish for current and future adaptation to climate change.

Author Contributions: Conceptualization, N.A. and M.S.; validation, M.L.R., M.S. and N.A.; data curation, M.L.R., M.S. and N.A.; writing—original draft preparation, M.L.R.; writing—review and editing, M.S. and N.A.; All authors read and confirm the manuscript. All authors have read and agreed to the published version of the manuscript.

Funding: This study received no external funding.

Institutional Review Board Statement: Not applicable.

Informed Consent Statement: Not applicable.

Data Availability Statement: Not applicable.

Conflicts of Interest: The authors declare no conflict of interest.

\section{References}

1. FAO. The State of World Fisheries and Aquaculture; FAO: Rome, Italy, 2020; pp. 21-23.

2. FRSS. Yearbook of Fisheries Statistics of Bangladesh; Fisheries Resources Survey System; Department of Fisheries, FRSS: Dhaka, Bangladesh, 2020.

3. Ahmed, N.; Diana, J.S. Threatening "white gold": Impacts of climate change on shrimp farming in coastal Bangladesh. Ocean Coast. Manag. 2015, 114, 42-52. [CrossRef]

4. Ahmed, N.; Diana, J.S. Does climate change matter for freshwater aquaculture in Bangladesh? Reg. Environ. Chang. 2016, 16, 1659-1669. [CrossRef]

5. Shelton, C. Climate Change Adaptation in Fisheries and Aquaculture: Compilation of Initial Examples; FAO Fisheries and Aquaculture Circular; Food and Agriculture Organization of the United Nations: Rome, Italy, 2014; pp. 1-25; 27-34.

6. De Silva, S.S.; Soto, D. Climate change and aquaculture: Potential impacts, adaptation and mitigation. In Climate change Implications for Fisheries and Aquaculture: Overview of Current Scientific Knowledge; FAO Fisheries and Aquaculture Technical Paper; FAO: Rome, Italy, 2009; Volume 530, pp. 151-212.

7. Mtaki, K.; Limbu, S.M.; Mmochi, A.J.; Mtolera, M.S. Hybrids production as a potential method to control prolific breeding in tilapia and adaptation to aquaculture climate-induced drought. Aquac. Fish. 2021. In press. [CrossRef]

8. Eckstein, D.; Künzel, V.; Schäfer, L.; Winges, M. Global Climate Risk Index 2020; Germanwatch: Bonn, Germany, 2019.

9. Trenberth, K.E. The impact of climate change and variability on heavy precipitation, floods, and droughts. Encycl. Hydrol. Sci. 2006.

10. Shahid, S. Rainfall variability and the trends of wet and dry periods in Bangladesh. Int. J. Climatol. 2010, 30, 2299-2313. [CrossRef]

11. Jakobsen, F.; Hoque, A.Z.; Paudyal, G.N.; Bhuiyan, S. Evaluation of the short-term processes forcing the monsoon river floods in Bangladesh. Water Int. 2005, 30, 389-399. [CrossRef] 
12. GoB. Bangladesh Climate Change Strategy and Action Plan 2009; Government of the People's Republic of Bangladesh: Dhaka, Bangladesh, 2009.

13. Shahid, S. Vulnerability of the power sector of Bangladesh to climate change and extreme weather events. Reg. Environ. Chang. 2012, 12, 595-606. [CrossRef]

14. Mirza, M.M.Q. Climate change, flooding in South Asia and implications. Reg. Environ. Chang. 2011, 11, 95-107. [CrossRef]

15. The World Bank. Bangladesh and Maldives Respond to Climate Change Impacts; Press Release. 7 December 2012. Available online: https: / /www.worldbank.org/en/news/press-release/2012/12/07/bangladesh-maldives-respond-to-climate-changeimpacts (accessed on 25 June 2021).

16. Habiba, U.; Shaw, R.; Takeuchi, Y. Farmer's perception and adaptation practices to cope with drought: Perspectives from Northwestern Bangladesh. Int. J. Disaster Risk Reduct. 2012, 1, 72-84. [CrossRef]

17. Selvaraju, R.; Baas, S. Climate Variability and Change: Adaptation to Drought in Bangladesh: A Resource Book and Training Guide; Food \& Agriculture Org.: Rome, Italy, 2007; Volume 9.

18. Dai, A.; Trenberth, K.E.; Qian, T. A global dataset of Palmer Drought Severity Index for 1870-2002: Relationship with soil moisture and effects of surface warming. J. Hydrometeorol. 2004, 5, 1117-1130. [CrossRef]

19. Conway, G.; Waage, J.; Delaney, S. Science and Innovation for Development; UK Collaborative on Development Sciences (UKCDS): London, UK, 2010.

20. Dasgupta, S.; Huq, M.; Khan, Z.H.; Ahmed, M.M.Z.; Mukherjee, N.; Khan, M.F.; Pandey, K. Cyclones in a changing climate: The case of Bangladesh. Clim. Dev. 2014, 6, 96-110. [CrossRef]

21. Monitoring, P.F.U. National Food Policy Plan of Action and Country Investment Plan Monitoring Report 2015; Ministry of Food, Government of the People's Republic of Bangladesh: Dhaka, Bangladesh, 2015.

22. Bureau, D.M. National Plan for Disaster Management, 2010-2015; Disaster Management \& Relief Division Dhaka (Bangladesh): Dhaka, Bangladesh, 2010.

23. Ahmad, H. Bangladesh coastal zone management status and future trends. Coast. Zone Manag. J. 2019, 22, 1-7.

24. Singh, O. Cause-effect relationships between sea surface temperature, precipitation and sea level along the Bangladesh coast. Theor. Appl. Climatol. 2001, 68, 233-243. [CrossRef]

25. Schiermeier, Q. Floods: Holding back the tide. Nat. News 2014, 508, 164. [CrossRef]

26. Pethick, J.; Orford, J.D. Rapid rise in effective sea-level in southwest Bangladesh: Its causes and contemporary rates. Glob. Planetary Chang. 2013, 111, 237-245. [CrossRef]

27. Rahmstorf, S. A semi-empirical approach to projecting future sea-level rise. Science 2007, 315, 368-370. [CrossRef] [PubMed]

28. Allison, M.A.; Khan, S.; Goodbred, S.L., Jr.; Kuehl, S.A. Stratigraphic evolution of the late Holocene Ganges-Brahmaputra lower delta plain. Sediment. Geol. 2003, 155, 317-342. [CrossRef]

29. Khan, A.E.; Ireson, A.; Kovats, S.; Mojumder, S.K.; Khusru, A.; Rahman, A.; Vineis, P. Drinking water salinity and maternal health in coastal Bangladesh: Implications of climate change. Environ. Health Perspect. 2011, 119, 1328-1332. [CrossRef]

30. Dailidienè, I.; Baudler, H.; Chubarenko, B.; Navrotskaya, S. Long term water level and surface temperature changes in the lagoons of the southern and eastern Baltic. Oceanologia 2011, 53, 293-308. [CrossRef]

31. Chowdhury, S.R.; Hossain, M.S.; Shamsuddoha, M.; Khan, S. Coastal Fishers' Livelihood in Peril: Sea Surface Temperature and Tropical Cyclones in Bangladesh; Center for Participatory Research and Development Dhaka: Dhaka, Bangladesh, 2012.

32. Ficke, A.D.; Myrick, C.A.; Hansen, L.J. Potential impacts of global climate change on freshwater fisheries. Rev. Fish. Biol. Fish. 2007, 17, 581-613. [CrossRef]

33. Rahman, A.K.A. Introduction of Exotic Fishes in Bangladesh; (booklet); Fisheries Research and Training Centre: Dhaka, Bangladesh, 1985.

34. Gupta, M.; Ahmed, M.; Bimbao, M.; Lightfoot, C. Socio-Economic Impact and Farmers Assessment of Nile Tilapia (Oreochromis niloticus) Culture in Bangladesh; Technical Report; International Centre for Living Aquatic Resource Management (ICLARM): Manila, Philippines, 1994; p. 35.

35. ADB. An Impact Evaluation of the Development of Genetically Improved Farmed Tilapia and Their Dissemination in Selected Countries; ADB: Mandaluyong, Philippines, 2005.

36. Alam, M.F.; Khan, M.A.; Huq, A.A. Technical efficiency in tilapia farming of Bangladesh: A stochastic frontier production approach. Aquac. Int. 2012, 20, 619-634. [CrossRef]

37. Hussain, M. Farming of tilapia: Breeding plans, mass seed production and aquaculture techniques. Habiba Akter Hussain 2004, 55, 149.

38. Ponzoni, R.W.; Khaw, H.L.; Yee, H.Y. GIFT: The Story Since Leaving ICLARM (Now Known as the WorldFish Center): Socioeconomic, Access and Benefit Sharing and Dissemination Aspects; FNI Report 14/2010; Fridtjof Nanesn Institute: Lysaker, Norway, 2010 ; p. 47.

39. Hussain, M.; Kohinoor, A.; Islam, M.; Mahata, S.; Ali, M.; Tanu, M.; Hossain, M.; Mazid, M. Genetic evaluation of GIFT and existing strains of Nile Tilapia, Oreochromis niloticus L., under on-station and on-farm conditions in Bangladesh. Asian Fish. Sci. 2000, 13, 117-126.

40. Hussain, M. A future for the tilapia in Bangladesh. AQUA Culture Asia Pacific Magazine. 2009, pp. 38-40. Available online: https:/ / www.boblme.org/documentRepository/Hussain\%20from\%20AQ09024_AquaJulAug-7.pdf (accessed on 8 July 2021).

41. ADB. An Evaluation of Small-scale Freshwater Rural Aquaculture Development for Poverty Reduction; ADB: Mandaluyong, Philippines, 2005. 
42. Ahmed, N.; Young, J.A.; Dey, M.M.; Muir, J.F. From production to consumption: A case study of tilapia marketing systems in Bangladesh. Aquac. Int 2012, 20, 51-70. [CrossRef]

43. Maclean, J.L. Tilapia: The aquatic chicken. ICLARM Newsl. 1984, 7, 17.

44. Smith, I.R.; Pullin, R.S.V. Tilapia production booms in the Philippines. ICLARM Newsl. 1984, 7, 7-9.

45. Report: A Comprehensive Study on High Value Fish (Tilapia, Pangas and Koi) in Bangladesh; Innovision Consulting Private Limited: Dhaka, Bangladesh, 2013; pp. 17-18.

46. Rahman, M.M.; Varga, I.; Chowdhury, S.N. Manual on Polyculture and Integrated Fish Farming in Bangladesh; Food and Agriculture Organization of the United Nations: Rome, Italy, 1992.

47. Perschbacher, P.W.; Stickney, R.R. Tilapia in Intensive Co-Culture; Wiley Online Library: Hoboken, NJ, USA, 2017 ; Volume 368.

48. Rahman, M.M.; Verdegem, M.; Wahab, M.A. Effects of tilapia (Oreochromis niloticus L.) stocking and artificial feeding on water quality and production in rohu-common carp bi-culture ponds. Aquac. Res. 2008, 39, 1579-1587.

49. Shahin, J.; Mondal, M.; Wahab, M.; Kunda, M. Effects of addition of tilapia in carp-prawn-mola polyculture system. J. Bangladesh Agric. Univ. 2011, 9, 147-158. [CrossRef]

50. Asaduzzaman, M.; Wahab, M.; Verdegem, M.; Mondal, M.; Azim, M. Effects of stocking density of freshwater prawn Macrobrachium rosenbergii and addition of different levels of tilapia Oreochromis niloticus on production in $\mathrm{C} / \mathrm{N}$ controlled periphyton based system. Aquaculture 2009, 286, 72-79. [CrossRef]

51. Khan, M.; Khan, M.; Akter, N.; Wahab, M. Strain performance of tilapia in freshwater prawn polyculture. J. Bangladesh Agric. Univ. 2016, 14, 127-134. [CrossRef]

52. Uddin, S.; Ekram-Ul-Azim, M.; Wahab, A.; Verdegem, M.C. The potential of mixed culture of genetically improved farmed tilapia (Oreochromis niloticus) and freshwater giant prawn (Macrobrachium rosenbergii) in periphyton-based systems. Aquac. Res. 2006, 37, 241-247. [CrossRef]

53. Sultana, N.; Hossain, M.A.; Reza, M.S. Effect of dietary protein level on the growth of giant freshwater prawn (Macrobrachium rosenbergii) and tilapia (Oreochromis niloticus) under polyculture system in northern Bangladesh. Int. J. Fish. Aquat. Stud. 2016, 4, 472-476.

54. Sharmin, F.; Rahman, M.; Shahjahan, M.; Chowdhury, P. Study of growth and productions of tilapia (Oreochromis niloticus) on different population densities in monoculture. Int. J. Agric. Res. Innov. Technol. 2019, 9, 76-83. [CrossRef]

55. Majumder, T.; Chowdhury, P.; Shahjahan, M.; Rahman, M. Effects of population density on growth and production of tilapia in monoculture. Int. J. Agric. Res. Innov. Technol. 2017, 7, 49-56. [CrossRef]

56. Rahman, M.M.; Chowdhury, P.; Islam, M. Effects of stocking density on growth and production performance of monosex male tilapia (Oreochromis niloticus) in earthen ponds. Int. J. Fish. Aquat. Stud. 2016, 4, 267-271.

57. Karim, M.; Zafar, A.; Ali, M. Growth and production of monosex tilapia (Oreochromis niloticus) under different feeding frequencies in pond conditons. J. Aquac. Mar. Biol 2017, 6, 00167.

58. Moniruzzaman, M.; Uddin, K.B.; Basak, S.; Mahmud, Y.; Zaher, M.; Bai, S.C. Effects of stocking density on growth, body composition, yield and economic returns of monosex tilapia (Oreochromis niloticus L.) under cage culture system in Kaptai Lake of Bangladesh. J. Aquac. Res. Dev. 2015, 6, 1. [CrossRef]

59. Begum, N.; Islam, M.; Haque, A.; Suravi, I. Growth and yield of monosex tilapia Oreochromis niloticus in floating cages fed commercial diet supplemented with probiotics in freshwater pond, Sylhet. Bangladesh J. Zool 2017, 45, 27-36. [CrossRef]

60. Huchette, S.; Beveridge, M. Technical and economical evaluation of periphyton-based cage culture of tilapia (Oreochromis niloticus) in tropical freshwater cages. Aquaculture 2003, 218, 219-234. [CrossRef]

61. Yaro, I.; Lamai, S.; Oladimeji, A. The effect of different fertilizer treatments on water quality parameters in rice-cum-fish culture systems. J. Appl. Ichthyol. 2005, 21, 399-405. [CrossRef]

62. Frei, M.; Razzak, M.; Hossain, M.; Oehme, M.; Dewan, S.; Becker, K. Performance of common carp, Cyprinus carpio L. and Nile tilapia, Oreochromis niloticus (L.) in integrated rice-fish culture in Bangladesh. Aquaculture 2007, 262, 250-259. [CrossRef]

63. Hossain, M.A.; Mridha, M.A.R.; Shah, A.K.M.A.; Nahiduzzaman, M.; Uddin, M.S. Performance of mono-sex tilapia (Oreochromis niloticus) in rice field with different ditch size. Aquac. Res. 2015, 46, 1891-1901. [CrossRef]

64. Billah, M.M.; Uddin, M.K.; Samad, M.Y.; Hassan, M.Z.; Anwar, M.P.; Kamal, A.H.; Shahjahan, M. Effects of different stocking density of Nile tilapia (Oreochromis niloticus) and common carp (Cyprinus carpio) on the growth performance and rice yield in rice-fish farming system. Aquac. Aquar. Conserv. Legis. 2020, 13, 789-803.

65. Kunda, M.; Azim, M.E.; Wahab, M.A.; Dewan, S.; Majid, M.A.; Thilsted, S.H. Effects of including catla and tilapia in a freshwater prawn-mola polyculture in a rotational rice-fish culture systems. Aquac. Res. 2009, 40, 1089-1098. [CrossRef]

66. Billah, M.M.; Uddin, M.K.; Samad, M.Y.; Hassan, M.Z.; Anwar, M.P.; Kamal, A.H.M.; Shahjahan, M. Fertilization effects on the growth of common carp (Cyprinus carpio) and Nile tilapia (Oreochromis niloticus) and rice yields in an integrated rice-fish farming system. Aquac. Aquar. Conserv. Legis. 2019, 12, 121-132.

67. Barman, B.K.; Little, D.C. Nile tilapia (Oreochromis niloticus) seed production in irrigated rice-fields in Northwest Bangladesh-an approach appropriate for poorer farmers? Aquaculture 2006, 261, 72-79. [CrossRef]

68. Frei, M.; Khan, M.; Razzak, M.; Hossain, M.; Dewan, S.; Becker, K. Effects of a mixed culture of common carp, Cyprinus carpio L., and Nile tilapia, Oreochromis niloticus (L.), on terrestrial arthropod population, benthic fauna, and weed biomass in rice fields in Bangladesh. Biol. Control. 2007, 41, 207-213. [CrossRef] 
69. Hossain, A. Assistance to Fisheries Research Institute-Report Prepared by a National Consultant on Pen Culture; Fisheries Research Institute: Mymensingh, Bangladesh, 2008.

70. Azad, A.K.; Jensen, K.R.; Lin, C.K. Coastal aquaculture development in Bangladesh: Unsustainable and sustainable experiences. Environ. Manag. 2009, 44, 800-809. [CrossRef]

71. Kais, S.M.; Islam, M.S. Impacts of and resilience to climate change at the bottom of the shrimp commodity chain in Bangladesh: A preliminary investigation. Aquaculture 2018, 493, 406-415. [CrossRef]

72. Alam, M.; Islam, M.; Tuong, T.P. Introducing tilapia (GIFT) with shrimp (Penaues monodon) in brackishwater rice-shrimp system: Impact on water quality and production. Bangladesh J. Fish. Res. 2008, 12, 187-195.

73. Saha, S.; Khatun, M. Production performances of monosex nile tilapia, Oreochromis niloticus in brackishwater ponds. Bangladesh J. Zool 2014, 42, 261-269. [CrossRef]

74. Shofiquzzoha, A.; Alam, M. Culture feasibility of silver barb (Barbodes gonionotus Bleeker) and GIFT with shrimp (Penaeus monodon Feb.) in brackishwater pond. Bangladesh J. Fish. Res. 2008, 12, 69-74.

75. Gutiérrez, J.C.; Ponce-Palafox, J.T.; Pineda-Jaimes, N.B.; Arenas-Fuentes, V.; Arredondo-Figueroa, J.L.; Cifuentes-Lemus, J.L. The feeding ecology of penaeid shrimp in tropical lagoon-estuarine systems/Ecología alimentaria de camarones peneidos en los sistemas lagunar-estuarinos tropicales. Gayana 2016, 80, 16. [CrossRef]

76. Tsadik, G.G.; Bart, A.N. Effects of feeding, stocking density and water-flow rate on fecundity, spawning frequency and egg quality of Nile tilapia, Oreochromis niloticus (L.). Aquaculture 2007, 272, 380-388. [CrossRef]

77. Hossain, M.; Roy, R.; Rahmatullah, S.; Kohinoor, A. Effect of stocking density on the growth and survival of GIFT tilapia,(Oreochromis niloticus) fed on formulated diet. J. Agric. Rural Dev. 2004, 2, 127-133.

78. Fitzsimmons, K. Development of new products and markets for the global tilapia trade. In Proceedings of the Sixth International Symposium on Tilapia in Aquaculture, Manila, Philippines, 12-16 September 2004; pp. 624-633.

79. ICLARM. Dissemination and Evaluation of Genetically Improved Tilapia Species in Asia (DEGITA): Technical Report (Nov 1994 to Jun 1995); International Center for Living Aquatic Resources Management (ICLARM): Manila, Philippines, 1995; 88p.

80. Saha, S.; Moniruzzaman, M.; Alam, M. Concurrent culture of shrimp and tilapia in coastal pond. Bangladesh J. Agric. 2012, 37, $11-16$.

81. Saha, S.; Moniruzzaman, M.; Alam, M. Optimization of stocking density of black tiger shrimp (Penaeus monodon) for concurrent culture with genetically improved farmed tilapia (GIFT) in brackishwater ghers. Bangladesh J. Zool 2009, 37, 175-182.

82. Islam, M.; Mahmud, Y. Performance of Fresh Water Prawn with Tilapia and Rui in Brakishwater Pond. SAARC J. Agri. 2011, 9 , 107-121.

83. Nabi, M.; Halim, M.A.; Nahar, S. Study on Production Performance and Economic of Mono-Sex Tilapia Culture at Marginal Farmer's Ponds in Gopalgonj Bangladesh. Int. J. Fish. Aquat. Stud. 2017, 5, 104-108.

84. Rahman, M.A.; Toky, M.T.; Islam, M.S.; Mukta, M.-A. Economic analysis of tilapia-carp polyculture in a selected area of Bangladesh. Arch. Agric. Environ. Sci. 2020, 5, 354-362. [CrossRef]

85. Ardjosoediro, I.; Ramnarine, I.W. The influence of turbidity on growth, feed conversion and survivorship of the Jamaica red tilapia strain. Aquaculture 2002, 212, 159-165. [CrossRef]

86. Garcia-Santos, S.; Fontaínhas-Fernandes, A.; Wilson, J.M. Cadmium tolerance in the Nile tilapia (Oreochromis niloticus) following acute exposure: Assessment of some ionoregulatory parameters. Environ. Toxicol. Int. J. 2006, 21, 33-46. [CrossRef] [PubMed]

87. Abdel-Tawwab, M.; Hagras, A.E.; Elbaghdady, H.A.M.; Monier, M.N. Effects of dissolved oxygen and fish size on Nile tilapia, Oreochromis niloticus (L.): Growth performance, whole-body composition, and innate immunity. Aquac. Int. 2015, 23, 1261-1274. [CrossRef]

88. Farm, M.A. Temperature and Low Dissolved Oxygen Tolerances for Tilapia. Available online: https://mweafish.com/ aquaculture-articles / 25-temperature-and-low-dissolved-oxygen-tolerances-for-tilapia.html (accessed on 18 May 2021).

89. El-Sayed, A.-F.M.; El-Ghobashy, A.; Al-Amoudi, M. Effects of pond depth and water temperature on the growth, mortality and body composition of Nile tilapia, Oreochromis niloticus (L.). Aquacult. Res. 1996, 27, 681-687. [CrossRef]

90. Hosen, M.H.A.; Sarker, K.; Chhanda, M.S.; Gupta, N. Effects of water depth on growth performance of Indian major carps at a poly culture system in Bangladesh. Int. J. Aquac. Fish. Sci. 2019, 5, 14-21. [CrossRef]

91. Baras, E.; Jacobs, B.; Mélard, C. Effect of water temperature on survival, growth and phenotypic sex of mixed (XX-XY) progenies of Nile tilapia Oreochromis niloticus. Aquaculture 2001, 192, 187-199. [CrossRef]

92. Azaza, M.; Dhraïef, M.; Kraïem, M. Effects of water temperature on growth and sex ratio of juvenile Nile tilapia Oreochromis niloticus (Linnaeus) reared in geothermal waters in southern Tunisia. J. Therm. Biol. 2008, 33, 98-105. [CrossRef]

93. Pandit, N.; Nakamura, M. Effect of high temperature on survival, growth and feed conversion ratio of Nile tilapia, Oreochromis niloticus. Our Nat. 2010, 8, 219-224. [CrossRef]

94. Xie, S.; Zheng, K.; Chen, J.; Zhang, Z.; Zhu, X.; Yang, Y. Effect of water temperature on energy budget of Nile tilapia, Oreochromis niloticus. Aquac. Nutr. 2011, 17, e683-e690. [CrossRef]

95. Qiang, J.; Yang, H.; Wang, H.; Kpundeh, M.; Xu, P. Growth and IGF-I response of juvenile Nile tilapia (Oreochromis niloticus) to changes in water temperature and dietary protein level. J. Therm. Biol. 2012, 37, 686-695. [CrossRef]

96. Islam, S.M.; Sultana, R.; Imran, M.; Jannat, M.F.T.; Ashaf-Ud-Doulah, M.; Rohani, M.F.; Brown, C.; Shahjahan, M. Elevated temperature affects growth and hemato-biochemical parameters, inducing morphological abnormalities of erythrocytes in Nile tilapia Oreochromis niloticus. Aquac. Res. 2020, 51, 4361-4371. [CrossRef] 
97. Wang, L.H.; Tsai, C.L. Effects of temperature on the deformity and sex differentiation of tilapia, Oreochromis mossambicus. J. Exp. Zool 2000, 286, 534-537. [CrossRef]

98. Desprez, D.; Mélard, C. Effect of ambient water temperature on sex determinism in the blue tilapia Oreochromis aureus. Aquaculture 1998, 162, 79-84. [CrossRef]

99. Dominguez, M.; Takemura, A.; Tsuchiya, M. Effects of changes in environmental factors on the non-specific immune response of Nile tilapia, Oreochromis niloticus L. Aquac. Res. 2005, 36, 391-397. [CrossRef]

100. Santo, A.H.E.; de Alba, G.; da Silva Reis, Y.; Costa, L.S.; Sánchez-Vázquez, F.J.; Luz, R.K.; Ribeiro, P.A.P.; López-Olmeda, J.F. Effects of temperature regime on growth and daily rhythms of digestive factors in Nile tilapia (Oreochromis niloticus) larvae. Aquaculture 2020, 528, 735545. [CrossRef]

101. El-Sherif, M.S.; El-Feky, A.M.I. Performance of Nile tilapia (Oreochromis niloticus) fingerlings. II. Influence of different water temperatures. Int. J. Agric. Biol. 2009, 11, 1814-9596.

102. Allanson, B.; Bok, A.; Van Wyk, N. The influence of exposure to low temperature on Tilapia mossambica Peters (Cichlidae). II. Changes in serum osmolarity, sodium and chloride ionconcentrations. J. Fish. Biol. 1971, 3, 181-185. [CrossRef]

103. He, J.; Qiang, J.; Yang, H.; Xu, P.; Zhu, Z.; Yang, R. Changes in the fatty acid composition and regulation of antioxidant enzymes and physiology of juvenile genetically improved farmed tilapia Oreochromis niloticus (L.), subjected to short-term low temperature stress. J. Therm. Biol. 2015, 53, 90-97. [CrossRef] [PubMed]

104. Ma, X.; Qiang, J.; He, J.; Gabriel, N.; Xu, P. Changes in the physiological parameters, fatty acid metabolism, and SCD activity and expression in juvenile GIFT tilapia (Oreochromis niloticus) reared at three different temperatures. Fish. Physiol. Biochem. 2015, 41, 937-950. [CrossRef]

105. Yang, C.; Jiang, M.; Wen, H.; Tian, J.; Liu, W.; Wu, F.; Gou, G. Analysis of differential gene expression under low-temperature stress in Nile tilapia (Oreochromis niloticus) using digital gene expression. Gene 2015, 564, 134-140. [CrossRef] [PubMed]

106. Zhou, T.; Gui, L.; Liu, M.; Li, W.; Hu, P.; Duarte, D.F.; Niu, H.; Chen, L. Transcriptomic responses to low temperature stress in the Nile tilapia, Oreochromis niloticus. Fish Shellfish. Immunol. 2019, 84, 1145-1156. [CrossRef]

107. Allanson, B.R.; Noble, R. The tolerance of Tilapia mossambica (Peters) to high temperature. Trans. Am. Fish. Soc. 1964, 93, 323-332. [CrossRef]

108. Delaney, M.; Klesius, P.; Shelby, R. Cortisol response of Nile tilapia, Oreochromis niloticus (L.), to temperature changes. J. Appl. Aquac. 2005, 16, 95-104. [CrossRef]

109. Ashaf-Ud-Doulah, M.; Al Mamun, A.; Rahman, M.L.; Islam, S.M.; Jannat, R.; Hossain, M.A.R.; Shahjahan, M. High temperature acclimation alters upper thermal limits and growth performance of Indian major carp, rohu, Labeo rohita (Hamilton, 1822). J. Therm. Biol. 2020, 93, 102738. [CrossRef]

110. Ashaf-Ud-Doulah, M.; Islam, S.M.; Zahangir, M.M.; Islam, M.S.; Brown, C.; Shahjahan, M. Increased water temperature interrupts embryonic and larval development of Indian major carp rohu Labeo rohita. Aquac. Int. 2021, 29, 711-722. [CrossRef]

111. Ashaf-Ud-Doulah, M.; Shahjahan, M.; Islam, S.M.; Al-Emran, M.; Rahman, M.S.; Hossain, M.A.R. Thermal stress causes nuclear and cellular abnormalities of peripheral erythrocytes in Indian major carp, rohu Labeo rohita. J. Therm. Biol. 2019, 86, 102450. [CrossRef]

112. Das, T.; Pal, A.; Chakraborty, S.; Manush, S.; Dalvi, R.; Sarma, K.; Mukherjee, S. Thermal dependence of embryonic development and hatching rate in Labeo rohita (Hamilton, 1822). Aquaculture 2006, 255, 536-541. [CrossRef]

113. Rougeot, C.; Prignon, C.; Kengne, C.V.N.; Mélard, C. Effect of high temperature during embryogenesis on the sex differentiation process in the Nile tilapia, Oreochromis niloticus. Aquaculture 2008, 276, 205-208. [CrossRef]

114. King, M.; Sardella, B. The effects of acclimation temperature, salinity, and behavior on the thermal tolerance of Mozambique tilapia (Oreochromis mossambicus). J. Exp. Zool. Part A Ecol. Integr. Physiol. 2017, 327, 417-422. [CrossRef]

115. Jauncey, K. The effects of varying dietary protein level on the growth, food conversion, protein utilization and body composition of juvenile tilapias (Sarotherodon mossambicus). Aquaculture 1982, 27, 43-54. [CrossRef]

116. Sifa, L.; Chenhong, L.; Dey, M.; Gagalac, F.; Dunham, R. Cold tolerance of three strains of Nile tilapia, Oreochromis niloticus, in China. Aquaculture 2002, 213, 123-129. [CrossRef]

117. Wu, F.; Yang, C.; Wen, H.; Zhang, C.; Jiang, M.; Liu, W.; Tian, J.; Yu, L.; Lu, X. Improving low-temperature stress tolerance of tilapia, Oreochromis niloticus: A functional analysis of Astragalus membranaceus. J. World Aquac. Soc. 2019, 50, 749-762. [CrossRef]

118. Santos, V.B.d.; Mareco, E.A.; Dal Pai Silva, M. Growth curves of Nile tilapia (Oreochromis niloticus) strains cultivated at different temperatures. Acta Sci. 2013, 35, 235-242.

119. Rezk, M.A.; Kamel, E.A.; Ramadan, A.A.; Dunham, R.A. Comparative growth of Egyptian tilapias in response to declining water temperature. Aquaculture 2002, 207, 239-247. [CrossRef]

120. Khater, E.; Ali, S.; Mohamed, W. Effect of water temperature on masculinization and growth of Nile tilapia fish. J. Aquac. Res. Dev. 2017, 8, 1-5. [CrossRef]

121. Drummond, C.D.; Murgas, L.D.S.; Vicentini, B. Growth and survival of tilapia Oreochromis niloticus (Linnaeus, 1758) submitted to different temperatures during the process of sex reversal. Ciência Agrotecnologia 2009, 33, 895-902. [CrossRef]

122. Mirea, C.; Cristea, V.; Grecu, I.R.; Dediu, L. Influence of different water temperature on intensive growth performance of Nile tilapia Oreochromis niloticus Linnaeus 1758 in a recirculating aquaculture system. Lucr Ştiinţ Ser. Zooteh 2013, 60, $227-231$.

123. Sea Temperature Info. World Seawater Temperatures: Bangladesh. Satellite Data Web. Available online: https://seatemperature. info/bangladesh-water-temperature.html (accessed on 8 July 2021). 
124. Payne, A.; Fishelson, L.; Yaron, Z. Estuarine and salt tolerant tilapias. IS Tilapia Aquac. Nezaret 1983, 8, 524.

125. Assem, H. Optimum salinity for the growth of the telost, Oreochromis niloticus confirmed by the saturation kinetic model for physiological response. J. Egyptian-German Soc. Zool. 1995, 16, 41-52.

126. Lawson, E.; Anetekhai, M. Salinity tolerance and preference of hatchery reared Nile tilapia, Oreochromis niloticus (Linneaus 1758). Asian J. Agric. Res. 2011, 3, 104-110.

127. de Azevedo, R.V.; de Oliveira, K.F.; Flores-Lopes, F.; Teixeira-Lanna, E.A.; Takishita, S.S.; Tavares-Braga, L.G. Responses of Nile tilapia to different levels of water salinity. Lat. Am. J. Aquat Res. 2015, 43, 828-835. [CrossRef]

128. Kang'ombe, J.; Brown, J.A. Effect of salinity on growth, feed utilization, and survival of Tilapia rendalli under laboratory conditions. J. Appl. Aquac. 2008, 20, 256-271. [CrossRef]

129. Ulotu, E.E.; Mmochi, A.J.; Lamtane, H.A. Effect of salinity on the survival and growth of Rufiji Tilapia (Oreochromis urolepis urolepis) fry. West. Indian Ocean. J. Mar. Sci. 2016, 15, 31-37.

130. Iqbal, K.; Qureshi, N.; Ashraf, M.; Rehman, M.; Khan, N.; Javid, A.; Abbas, F.; Mushtaq, M.; Rasool, F.; Majeed, H. Effect of different salinity levels on growth and survival of Nile tilapia (Oreochromis niloticus). J. Anim. Plant Sci. 2012, 22, 919-922.

131. Gan, L.; Xu, Z.; Ma, J.; Xu, C.; Wang, X.; Chen, K.; Chen, L.; Li, E. Effects of salinity on growth, body composition, muscle fatty acid composition, and antioxidant status of juvenile Nile tilapia Oreochromis niloticus (Linnaeus, 1758). J. Appl. Ichthyol. 2016, 32, 372-374. [CrossRef]

132. Kabir Chowdhury, M.; Yi, Y.; Lin, C.; El-Haroun, E. Effect of salinity on carrying capacity of adult Nile tilapia Oreochromis niloticus L. in recirculating systems. Aquac. Res. 2006, 37, 1627-1635. [CrossRef]

133. de Alvarenga, É.R.; Alves, G.F.d.O.; Fernandes, A.F.A.; Costa, G.R.; da Silva, M.A.; Teixeira, E.d.A.; Turra, E.M. Moderate salinities enhance growth performance of Nile tilapia (Oreochromis niloticus) fingerlings in the biofloc system. Aquac. Res. 2018, 49, 2919-2926. [CrossRef]

134. Hasbullah, D.; Karim, M.; Zainuddin, Z.; Trijuno, D. The effect of salinity on the body chemical composition and RNA/DNA ratio of the hybrid brackishwater Nile tilapia Oreochromis niloticus. Aquac. Aquar. Conserv. Legis. 2018, 11, 943.

135. Tran-Ngoc, K.T.; Schrama, J.W.; Le, M.T.; Nguyen, T.H.; Roem, A.J.; Verreth, J.A. Salinity and diet composition affect digestibility and intestinal morphology in Nile tilapia (Oreochromis niloticus). Aquaculture 2017, 469, 36-43. [CrossRef]

136. El-Leithy, A.A.; Hemeda, S.A.; Abd El Naby, W.S.; El Nahas, A.F.; Hassan, S.A.; Awad, S.T.; El-Deeb, S.I.; Helmy, Z.A. Optimum salinity for Nile tilapia (Oreochromis niloticus) growth and mRNA transcripts of ion-regulation, inflammatory, stress-and immunerelated genes. Fish. Physiol. Biochem. 2019, 45, 1217-1232. [CrossRef] [PubMed]

137. Soegianto, A.; Adhim, M.d.H.; Zainuddin, A.; Putranto, T.W.C.; Irawan, B. Effect of different salinity on serum osmolality, ion levels and hematological parameters of East Java strain tilapia Oreochromis niloticus. Mar. Freshw. Behav. Physiol. 2017, 50, 105-113. [CrossRef]

138. Moorman, B.P.; Inokuchi, M.; Yamaguchi, Y.; Lerner, D.T.; Grau, E.G.; Seale, A.P. The osmoregulatory effects of rearing Mozambique tilapia in a tidally changing salinity. Gen. Comp. Endocrinol. 2014, 207, 94-102. [CrossRef]

139. Moorman, B.P.; Lerner, D.T.; Grau, E.G.; Seale, A.P. The effects of acute salinity challenges on osmoregulation in Mozambique tilapia reared in a tidally changing salinity. J. Exp. Biol. 2015, 218, 731-739. [CrossRef]

140. Rengmark, A.; Slettan, A.; Lee, W.; Lie, Ø.; Lingaas, F. Identification and mapping of genes associated with salt tolerance in tilapia. J. Fish. Biol. 2007, 71, 409-422. [CrossRef]

141. Watanabe, W.O.; French, K.E.; Ernst, D.H.; Olla, B.L.; Wicklund, R.I. Salinity during early development influences growth and survival of Florida red tilapia in brackish and seawater. J. World Aquac. Soc. 1989, 20, 134-142. [CrossRef]

142. El-Dahhar, A.; Kamel, E.A.; El-Wakil, H.; Grana, Y. Effect of salinity stress on growth of three strains of Egyptian Nile tilapia (Oreochromis niloticus). J. Arab. Aquac. Soc. 2011, 6, 251-269.

143. Moorman, B.P.; Yamaguchi, Y.; Lerner, D.T.; Grau, E.G.; Seale, A.P. Rearing Mozambique tilapia in tidally-changing salinities: Effects on growth and the growth hormone/insulin-like growth factor I axis. Comp. Biochem. Physiol. Part A Mol. Integr. Physiol. 2016, 198, 8-14. [CrossRef]

144. Burge, C.A.; Eakin, C.M.; Friedman, C.S.; Froelich, B.; Hershberger, P.K.; Hofmann, E.E.; Petes, L.E.; Prager, K.C.; Weil, E.; Willis, B.L. Ford, S.E.; Harvell, C.D. Climate Change Influences on Marine Infectious Diseases: Implications for Management and Society. Ann. Rev. Mar. Sci. 2014, 6, 249-277. [CrossRef]

145. Harvell, C.D.; Mitchell, C.E.; Ward, J.R.; Altizer, S.; Dobson, A.P.; Ostfeld, R.S.; Samuel, M.D. Climate warming and disease risks for terrestrial and marine biota. Science 2002, 296, 2158-2162. [CrossRef]

146. Altizer, S.; Ostfeld, R.S.; Johnson, P.T.; Kutz, S.; Harvell, C.D. Climate change and infectious diseases: From evidence to a predictive framework. Science 2013, 341, 514-519. [CrossRef] [PubMed]

147. Egan, S.; Gardiner, M. Microbial dysbiosis: Rethinking disease in marine ecosystems. Front. Microbiol. 2016, 7, 991. [CrossRef]

148. Byers, J.E. Marine parasites and disease in the era of global climate change. Ann. Rev. Mar. Sci. 2021, 13, 397-420. [CrossRef]

149. Lafferty, K.D. Marine Disease Ecology; Oxford University Press: Oxford, UK, 2020.

150. Sae-Lim, P.; Kause, A.; Mulder, H.; Olesen, I. Breeding and genetics symposium: Climate change and selective breeding in aquaculture. J. Anim. Sci. 2017, 95, 1801-1812. [CrossRef]

151. Plumb, J.A. Infectious diseases of tilapia. Tilapia Aquac. Am. 1997, 1, 212-228.

152. Cai, W.; Li, S.; Ma, J. Diseases resistance of Nile tilapia (Oreochromis niloticus), blue tilapia (Oreochromis aureus) and their hybrid (female Nile tilapia $\times$ male blue tilapia) to Aeromonas sobria. Aquaculture 2004, 229, 79-87. [CrossRef] 
153. Barría, A.; Trinh, T.Q.; Mahmuddin, M.; Benzie, J.A.; Chadag, V.M.; Houston, R.D. Genetic parameters for resistance to Tilapia Lake Virus (TiLV) in Nile tilapia (Oreochromis niloticus). Aquaculture 2020, 522, 735126. [CrossRef]

154. Wonmongkol, P.; Sukhavachana, S.; Ampolsak, K.; Srisapoome, P.; Suwanasopee, T.; Poompuang, S. Genetic parameters for resistance against Flavobacterium columnare in Nile tilapia Oreochromis niloticus (Linnaeus, 1758). J. Fish. Dis 2018, 41, 321-328. [CrossRef] [PubMed]

155. Sukhavachana, S.; Tongyoo, P.; Massault, C.; McMillan, N.; Leungnaruemitchai, A.; Poompuang, S. Genome-wide association study and genomic prediction for resistance against Streptococcus agalactiae in hybrid red tilapia (Oreochromis spp.). Aquaculture 2020, 525, 735297. [CrossRef]

156. Inglis, V.; Robert, R.J.; Bromage, N.R. Bacterial Disease of Fish London; Blackwell Science Ltd.: London, UK, 1993 ; pp. $196-207$.

157. Klesius, P.; Shoemaker, C.; Evans, J. Streptococcus: A worldwide fish health problem. In Proceedings of the 8th International Symposium on Tilapia in Aquaculture, Cairo, Egypt, 12-14 October 2008; Volume 1, pp. 83-107.

158. Xia, Y.; Wang, M.; Gao, F.; Lu, M.; Chen, G. Effects of dietary probiotic supplementation on the growth, gut health and disease resistance of juvenile Nile tilapia (Oreochromis niloticus). Anim. Nutr. 2020, 6, 69-79. [CrossRef] [PubMed]

159. Gabriel, N.N.; Qiang, J.; He, J.; Ma, X.Y.; Kpundeh, M.D.; Xu, P. Dietary Aloe vera supplementation on growth performance, some haemato-biochemical parameters and disease resistance against Streptococcus iniae in tilapia (GIFT). Fish. Shellfish Immunol. 2015, 44, 504-514. [CrossRef]

160. Van Doan, H.; Hoseinifar, S.H.; Sringarm, K.; Jaturasitha, S.; Yuangsoi, B.; Dawood, M.A.; Esteban, M.Á.; Ringø, E.; Faggio, C. Effects of Assam tea extract on growth, skin mucus, serum immunity and disease resistance of Nile tilapia (Oreochromis niloticus) against Streptococcus agalactiae. Fish. Shellfish Immunol. 2019, 93, 428-435. [CrossRef]

161. Wu, Y.-r.; Gong, Q.-f.; Fang, H.; Liang, W.-w.; Chen, M.; He, R.-J. Effect of Sophora flavescens on non-specific immune response of tilapia (GIFT Oreochromis niloticus) and disease resistance against Streptococcus agalactiae. Fish. Shellfish Immunol. 2013, 34, $220-227$. [CrossRef] [PubMed]

162. Van Doan, H.; Hoseinifar, S.H.; Tapingkae, W.; Seel-Audom, M.; Jaturasitha, S.; Dawood, M.A.; Wongmaneeprateep, S.; Thu, T.T.N.; Esteban, M.Á. Boosted growth performance, mucosal and serum immunity, and disease resistance Nile tilapia (Oreochromis niloticus) fingerlings using corncob-derived xylooligosaccharide and Lactobacillus plantarum CR1T5. Probiotics Antimicro 2020, 12, 400-411. [CrossRef]

163. Ibrahim, R.E.; Ahmed, S.A.; Amer, S.A.; Al-Gabri, N.A.; Ahmed, A.I.; Abdel-Warith, A.-W.A.; Younis, E.-S.M.; Metwally, A.E. Influence of vitamin $C$ feed supplementation on the growth, antioxidant activity, immune status, tissue histomorphology, and disease resistance in Nile tilapia, Oreochromis niloticus. Aquac. Rep. 2020, 18, 100545. [CrossRef]

164. Van Doan, H.; Hoseinifar, S.H.; Elumalai, P.; Tongsiri, S.; Chitmanat, C.; Jaturasitha, S.; Doolgindachbaporn, S. Effects of orange peels derived pectin on innate immune response, disease resistance and growth performance of Nile tilapia (Oreochromis niloticus) cultured under indoor biofloc system. Fish. Shellfish Immunol. 2018, 80, 56-62. [CrossRef]

165. Abdel-Tawwab, M.; Ahmad, M.H.; Seden, M.E.; Sakr, S.F. Use of green tea, Camellia sinensis L., in practical diet for growth and protection of Nile tilapia, Oreochromis niloticus (L.), against Aeromonas hydrophila infection. J. World Aquac. Soc. 2010, 41, 203-213. [CrossRef]

166. El-Sayed, H.M.; Hakim, Y.; El-Sayed, B.M. Dietary effect of ginger, Zingiber officinale Roscoe on growth performance, immmune response of Nile tilapia, Oreochromis niloticus and disease resistance against Aeromonas hydrophila. Abbassa Int. J. Aquac. 2014, 7 , 35-52.

167. Abdel Rahman, A.N.; ElHady, M.; Hassanin, M.E. Effect of Indian lotus (Nelumbo nucifera Gaertn.) leaf powder on immune status and disease resistance of Nile tilapia. Aquac. Res. 2018, 49, 3392-3399. [CrossRef]

168. Pumchan, A.; Krobthong, S.; Roytrakul, S.; Sawatdichaikul, O.; Kondo, H.; Hirono, I.; Areechon, N.; Unajak, S. Novel Chimeric Multiepitope Vaccine for Streptococcosis Disease in nile tilapia (Oreochromis niloticus Linn.). Sci. Rep. 2020, 10, 603. [CrossRef] [PubMed]

169. Zhang, D.; Gao, Y.; Li, Q.; Ke, X.; Liu, Z.; Lu, M.; Shi, C. An effective live attenuated vaccine against Streptococcus agalactiae infection in farmed Nile tilapia (Oreochromis niloticus). Fish. Shellfish Immunol. 2020, 98, 853-859. [CrossRef] [PubMed]

170. Shirajum Monir, M.; Yusoff, S.M.; Mohamad, A.; Ina-Salwany, M. Vaccination of tilapia against Motile Aeromonas Septicemia: A review. J. Aquat. Anim. Health 2020, 32, 65-76. [CrossRef] [PubMed]

171. Tattiyapong, P.; Dechavichitlead, W.; Waltzek, T.B.; Surachetpong, W. Tilapia develop protective immunity including a humoral response following exposure to tilapia lake virus. Fish. Shellfish Immunol. 2020, 106, 666-674. [CrossRef] [PubMed]

172. Corbeil, S.; Kurath, G.; Lapatra, S.E. Fish DNA vaccine against infectious hematopoietic necrosis virus: Efficacy of various routes of immunisation. Fish. Shellfish Immunol. 2000, 10, 711-723. [CrossRef] [PubMed]

173. Liao, P.-C.; Tsai, Y.-L.; Chen, Y.-C.; Wang, P.-C.; Liu, S.-C.; Chen, S.-C. Analysis of Streptococcal Infection and Correlation with Climatic Factors in Cultured Tilapia Oreochromis spp. in Taiwan. Appl. Sci. 2020, 10, 4018. [CrossRef] 